\title{
Sareomycetes cl. nov. : A new proposal for placement of the resinicolous genus Sarea (Ascomycota, Pezizomycotina)
}

\section{Beimforde, Christina}

2020-12

Beimforde , C , Schmidt, A R , Rikkinen, J \& Mitchell , J K 2020 , ' Sareomycetes cl. nov. A new proposal for placement of the resinicolous genus Sarea (Ascomycota, Pezizomycotina) ' , Fungal Systematics and Evolution, vol. 6 , pp. 25-37 . https://doi.org/10.3114/fuse.2020.06.02

http://hdl.handle.net/10138/317218

https://doi.org/10.3114/fuse.2020.06.02

cc_by_nc_sa

publishedVersion

Downloaded from Helda, University of Helsinki institutional repository.

This is an electronic reprint of the original article.

This reprint may differ from the original in pagination and typographic detail.

Please cite the original version. 
doi.org/10.3114/fuse.2020.06.02

\title{
Sareomycetes cl. nov.: A new proposal for placement of the resinicolous genus Sarea (Ascomycota, Pezizomycotina)
}

\author{
C. Beimforde ${ }^{1 *}$, A.R. Schmidt ${ }^{1}$, J. Rikkinen ${ }^{2}$, J.K. Mitchell ${ }^{3}$
}

${ }^{1}$ Department of Geobiology, University of Göttingen, Goldschmidtstraße 3, 37077 Göttingen, Germany

${ }^{2}$ Finnish Museum of Natural History, P.O. Box 7, 00014 University of Helsinki, Finland, and Organismal and Evolutionary Biology Research Programme, Faculty of Biological and Environmental Sciences, P.O. Box 65, 00014 University of Helsinki, Finland

${ }^{3}$ Department of Physics, Harvard University, 17 Oxford Street, Cambridge, MA 02138 and Farlow Reference Library and Herbarium of Cryptogamic Botany, 22 Divinity Avenue, Cambridge, MA 02138, USA

\section{*Corresponding author: christina.beimforde@uni-goettingen.de}

Key words:

Ascomycota

new taxa

resinicolous fungi

Sarea difformis

Sarea resinae

Sareomycetes cl. nov.

Sareales ord. nov.

Sareaceae fam. nov.

taxonomy

Corresponding editor:

P.W. Crous

\begin{abstract}
Resinicolous fungi constitute a heterogeneous assemblage of fungi that live on fresh and solidified plant resins. The genus Sarea includes, according to current knowledge, two species, S. resinae and S. difformis. In contrast to other resinicolous discomycetes, which are placed in genera also including non-resinicolous species, Sarea species only ever fruit on resin. The taxonomic classification of Sarea has proven to be difficult and currently the genus, provisionally and based only on morphological features, has been assigned to the Trapeliales (Lecanoromycetes). In contrast, molecular studies have noted a possible affinity to the Leotiomycetes. Here we review the taxonomic placement of Sarea using sequence data from seven phylogenetically informative DNA regions including ribosomal (ITS, nucSSU, mtSSU, nucLSU) and protein-coding ( $r p b 1, r p b 2, \mathrm{mcm} 7)$ regions. We combined available and new sequence data with sequences from major Pezizomycotina classes, especially Lecanoromycetes and Leotiomycetes, and assembled three different taxon samplings in order to place the genus Sarea within the Pezizomycotina. Based on our data, none of the applied phylogenetic approaches (Bayesian Inference, Maximum Likelihood and Maximum Parsimony) supported the placement of Sarea in the Trapeliales or any other order in the Lecanoromycetes. A placement of Sarea within the Leotiomycetes is similarly unsupported. Based on our data, Sarea forms an isolated and highly supported phylogenetic lineage within the "Leotiomyceta". From the results of our multilocus phylogenetic analyses we propose here a new class, order, and family, Sareomycetes, Sareales and Sareaceae in the Ascomycota to accommodate the genus Sarea. The genetic variability within the newly proposed class suggests that it is a larger group that requires further infrageneric classification.
\end{abstract}

Effectively published online: 14 February 2020

\section{INTRODUCTION}

Many conifers and angiosperms have developed resin-based defence mechanisms to deter herbivores and microbial pathogens (Farrell et al. 1991, Gershenzon \& Dudareva 2007, Howe \& Schaller 2008). The sticky resin seals injuries in the trees and acts as a biochemical barrier due to terpenoid and phenolic compounds (Bednarek \& Osbourn 2009, Rautio et al. 2011, Sipponen \& Laitinen 2011, Seyfullah et al. 2018). However, certain fungi have developed resistance against toxic resin compounds (Rautio et al. 2011, Adams et al. 2013), and are able to colonize fresh and solidified resin (Tuovila et al. 2013). Resinicolous fungi represent a polyphyletic assemblage of ascomycetes which grow exclusively on tree resins (Tuovila 2013, Rikkinen et al. 2016).

Resinicolous fungi occur scattered throughout many classes within the Ascomycota. Most resinicolous fungi described to date are ascomycetes within the order Mycocaliciales (Eurotiomycetes) (e.g. Rikkinen 2003, Rikkinen et al. 2014, Tuovila et al. 2011a, b, 2012, Tuovila 2013). Sorocybe resinae (Chaetothyriales, Herpotrichiellaceae) and its synasexual morph
Hormodendrum resinae (Seifert et al. 2007), and S. oblongispora (Crous et al. 2019), represent asexual Eurotiomycetes that are also often found on resin. The association of these fungi with conifer resin has existed for at least $35 \mathrm{M}$ years as evidenced by fossilized specimens in Palaeogene amber (Rikkinen \& Poinar 2000, Tuovila et al. 2013, Beimforde et al. 2014, Rikkinen \& Schmidt 2018). While other resinicolous fungi have not received as much recent attention, a significant number occurs in other classes. Dothideomycetes contains at least six resinicolous species: Helicoma resinae, Mytilinidion resinae, M. resinicola, Strigopodia batistae, S. resinae, and Torula resinicola. Leotiomycetes boasts a similar number, with at least six resinicolous species: Bisporella resinicola, Claussenomyces kirschsteinianus, C. olivaceus, Hymenoscyphus resinae-piceae, Lachnellula resinaria, and Micropodia resinicola. A similar number of fungi are also currently not satisfactorily placed. Fungi such as Gyrocerus resinae and Moriola resinae have not been collected in over a century, while more recently collected fungi such as Bruceomyces castoris and Resinogalea humboldtensis are classified based on morphological characters due to the lack of molecular data (Rikkinen et al. 2016). Among this group of 
poorly placed fungi, two widely collected discomycetes in the genus Sarea are also found.

Sarea resinae and $S$. difformis are both found fruiting exclusively on conifer resins and often co-occur on the same substrate. These two fungi are the only presently known species in the genus Sarea, which was erected by Fries in 1825 . In contrast to other resinicolous discomycetes, which are placed in genera also including wood rotting species or parasites, Sarea species only ever fruit on resin. Both species are common in northern latitudes where they are usually found on resins of Picea and Pinus species, but also on other genera of Pinaceae including Abies, Larix and Pseudotsuga (Hawksworth \& Sherwood 1981), Cedrus (Malençon 1979) and Tsuga (Baranyay 1966). They have also been reported from exudates of Cupressaceae s. I. such as Chamaecyparis (Ayers 1941, Suto 1985), Cupressus (Hawksworth \& Sherwood 1981, Garrido-Benavent 2015), Cryptomeria (Suto 1985 ) and Juniperus (Petrini \& Carrol 1981) indicating a relatively broad host range.

Little has been conclusively shown about the ecology and evolutionary origin of the genus Sarea so far. Species of the genus have variously been treated as lichen symbionts (Mudd 1861, Koerber 1865, Nylander 1866, Ohlert 1870, Hasse 1898, 1908, Cappelletti 1924, Fink 1935, Watson 1948, Etayo 1996, Bartkowiak \& Bennett 2015) or mild to serious parasites (Kujala 1950, Conners 1967, Smerlis 1973, Funk 1981, Kobayashi \& Zhao 1989, Kuz'michev et al. 2001, Safronova \& Palnikova 2010, Bazhina \& Aminev 2012, Safronova \& Sorokin 2013). Currently they are mostly treated as saprobes (Hawksworth \& Sherwood 1981, Wirth 1995, Gadgil \& Dick 1999, Suto 2000, Robertson 2002, Czyżewska et al. 2005, Kukwa et al. 2008, Lõhmus et al. 2012, Łubek \& Jaroszewicz 2012, Szymczyk et al. 2014, GarridoBenavent 2015, Motiejūnaitė 2015, Yatsyna 2015, Himelbrant 2016, Kuznetsova et al. 2016, McMullin \& Lendemer 2016), but additionally have been regarded as endophytes (Petrini \& Carroll 1981, Petrini \& Fisher 1988, Kowalski \& Kehr 1992, Giordano et al. 2009, Koukol et al. 2012, Sanz-Ros et al. 2015).

The taxonomy of Sarea and its systematic assignment within the Pezizomycotina is still poorly resolved. Previously, Sarea species were placed in genera belonging to Lecanoromycetes, Leotiomycetes, and Pezizomycetes, including Biatora, Biatoriella, Lecidea, Tympanis, Biatoridium, Pezicula and Peziza (Hawksworth \& Sherwood 1981). Hawksworth \& Sherwood (1981) solved nomenclatural issues and provided detailed morphological descriptions of both Sarea species and placed the genus within Agyriaceae. Successive molecular studies suggested a relationship of Sarea to clades presently placed in Leotiomycetes (Reeb et al. 2004, Wang et al. 2006, 2009, LoBuglio \& Pfister 2010, Miadlikowska et al. 2014), as opposed to earlier morphological placement within Lecanoromycetes, but these authors could not satisfactorily place the genus into any class within Pezizomycotina. Based on morphological traits, Lumbsch \& Huhndorf (2010) and Hodkinson \& Lendemer (2011) provisionally placed Sarea within Trapeliaceae (Lecanoromycetes). However, the difficulty of excluding potential homoplasy of morphological traits is well known in fungal systematics (e.g. Berbee \& Taylor 1992, Schmitt et al. 2005, Lumbsch et al. 2007) and many studies show that morphological synapomorphies do not consequently correspond to monophyletic groups (e.g. Lumbsch et al. 2007, Prieto et al. 2013).

In this study, we aim to revise the current placement of Sarea in Trapeliales (Lecanoromycetes) with molecular data. Additionally, we aim to test the earlier suggestions of a placement within Leotiomycetes and calculate a phylogenetic hypothesis of Sarea and representatives of most Pezizomycotina classes. Only ribosomal sequences (nucLSU, nucSSU and 5.8S rDNA) of Sarea were available for phylogenetic studies so far and these may have provided insufficient information for accurate classification into the Pezizomycotina. Here we use seven phylogenetically informative DNA regions represented by ribosomal (ITS, nucSSU, mtSSU, nucLSU) and protein-coding ( $r p b 1, r p b 2, \mathrm{mcm} 7)$ sequences, of which four are new to the research community. Most sequences were obtained from in vitro cultures of Sarea resinae and $S$. difformis isolated from resin flows of Picea abies (Norway spruce). We combined the new sequence data with present sequences from major classes in Pezizomycotina in three different taxon samplings and applied the most current approaches including Bayesian Inference, Maximum Likelihood and Maximum Parsimony for the phylogenetic calculations.

\section{MATERIAL AND METHODS}

\section{Biological material}

Specimens of Sarea difformis and S. resinae originate from resin soaked bark or fresh, semi-solidified resin flows of Picea abies, Pseudotsuga menziesii and Abies sp. from coniferous forests in Finland, Germany and New Zealand. Sampled trees produced resin in response to mechanical damage due to animal or human activity or in response to microbial infections causing resinous canker lesions. Analysed specimens were deposited in the New Zealand Fungarium (PDD), Landcare Research in Auckland and in Helsinki $(\mathrm{H})$. The collection data are provided in Table 1. GenBank accession numbers are provided in the supplementary data Table S1.

Table 1. List of Sareomycetes examined in this study with information to their substrate, collection locality, voucher number and collection where the specimens are deposited.

\begin{tabular}{|c|c|c|c|c|}
\hline Taxon & Voucher & Substrate & Locality & Collection \\
\hline Sarea difformis s. I. & CB093 & resin, Picea abies & Göttingen, Lower Saxony, Germany & University of Helsinki (H), Helsinki \\
\hline Sarea difformis s. I. & JR6451 & resin, Picea abies & Finland & University of Helsinki $(\mathrm{H})$, Helsinki \\
\hline Sarea resinae s. I. & CB094 & resin, Picea abies & Göttingen, Lower Saxony, Germany & University of Helsinki $(\mathrm{H})$, Helsinki \\
\hline Sarea resinae s. I. & JR6450 & resin, Picea abies & Finland & University of Helsinki $(\mathrm{H})$, Helsinki \\
\hline Sarea resinae s. I. & PDD117345 & resin, Pseudotsuga menziesii & Dunedin, Otago, New Zealand & $\begin{array}{l}\text { New Zealand Fungarium (PDD) } \\
\text { Collection, Auckland }\end{array}$ \\
\hline Sarea resinae s. I. & PDD117343 & resin, Abies sp. & $\begin{array}{l}\text { Manapouri, Southland, New } \\
\text { Zealand }\end{array}$ & $\begin{array}{l}\text { New Zealand Fungarium (PDD) } \\
\text { Collection, Auckland }\end{array}$ \\
\hline
\end{tabular}




\section{Light microscopy}

Fungal specimens were studied and imaged under a Carl Zeiss StereoDiscovery V8 dissection microscope and a Carl Zeiss AxioScope A1 compound microscope equipped with Canon EOS
5D digital cameras. All images (Fig. 1) represent digitally stacked photomicrographs obtained from up to 50 focal layers merged with the software package HeliconFocus v. 6.33 Pro (Helicon Soft Limited, Kharkiv, Ukraine). For Fig. 1D, incident and transmitted light were used simultaneously. To study hyphal growth inside
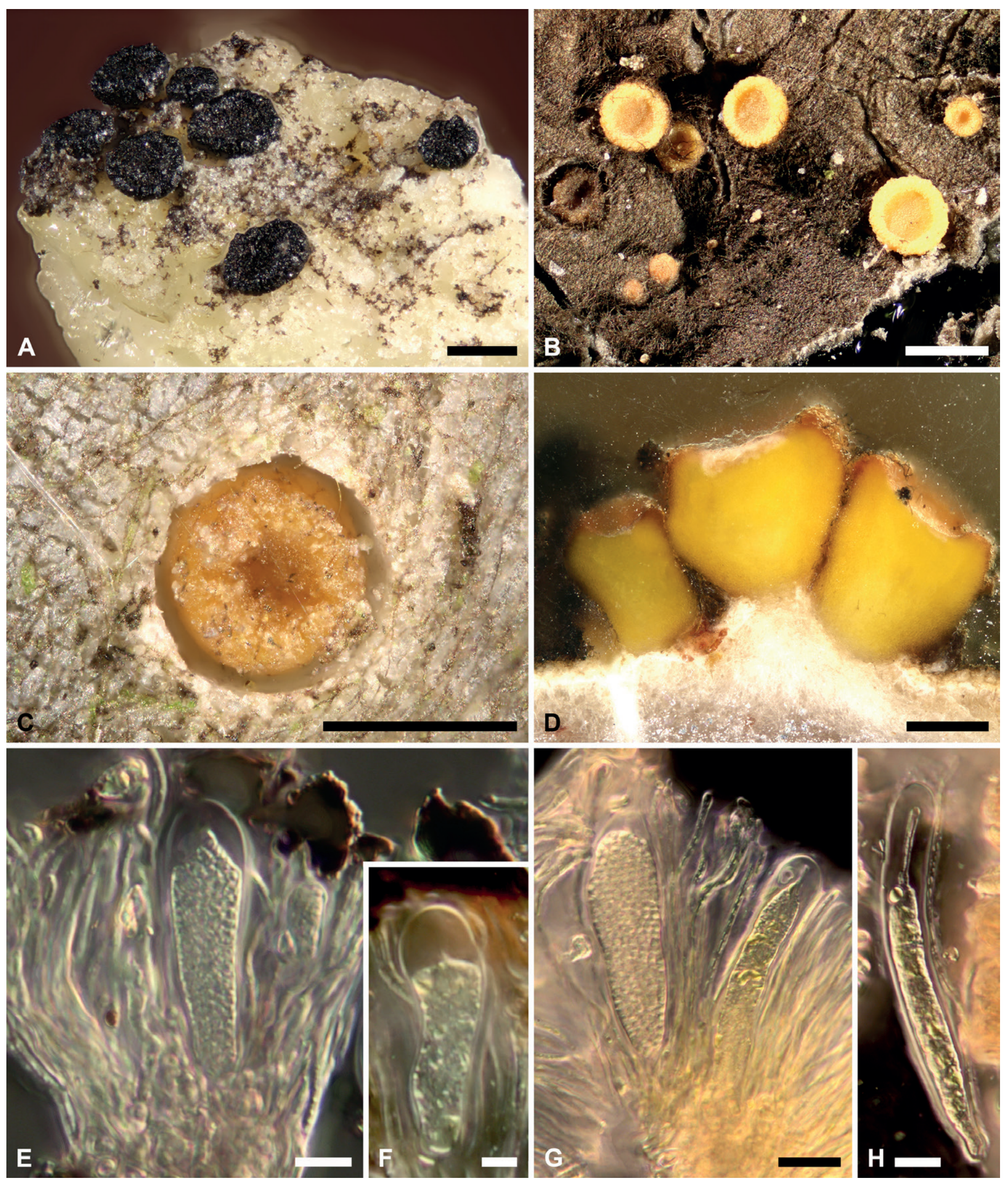

Fig. 1. Light micrographs of Sarea difformis and S. resinae. A. Ascomata of S. difformis and B. S. resinae; C. Young ascoma of S. resinae arising on a fresh resin flow; D. Cross-section of S. resinae showing hyphal growth into the liquid resin; E. Ascus and paraphyses of S. difformis; F. Young ascus of S. difformis; G. Asci and paraphyses of S. resinae; H. Young ascus of S. resinae. Scale bars: $1 \mathrm{~mm}(\mathrm{~A}, \mathrm{~B}), 500 \mu \mathrm{m}(\mathrm{C}, \mathrm{D}), 10 \mu \mathrm{m}(\mathrm{E}, \mathrm{G}), 5 \mu \mathrm{m}(\mathrm{F}, \mathrm{H})$. 
the resin bodies, samples were embedded in epoxy resin EpoTek 301-2 (Epoxy Technology, Inc; Massachusetts) and ground using gradually fine-grained emery paper. Ascomatal details of Sarea resinae and $S$. difformis (Fig. $1 \mathrm{E}-\mathrm{H}$ ) were studied under $40 \times$ to $100 \times$ magnification using $100 \times$ oil-immersion objective, sometimes with an additional 1.6-fold magnification (Fig. $1 \mathrm{H}$ ).

\section{Cultivation}

Ascospore germination was performed on solid malt yeast extract agar (MYA; $20 \mathrm{~g}$ malt extract, 2 g yeast extract, $20 \mathrm{~g}$ agar on $1000 \mathrm{~mL}$ distilled water, $\mathrm{pH}=6.5-7)$, malt extract agar (MEA; $20 \mathrm{~g}$ malt extract, $1 \mathrm{~g}$ peptone, $20 \mathrm{~g}$ glucose, $20 \mathrm{~g}$ agar in $1000 \mathrm{~mL}$ distilled water, $\mathrm{pH}=5-5.5$ ) and potato dextrose agar (PDA; pre-formulated media, Carl Roth, Germany, $\mathrm{pH}=5.6$ \pm 0.2 ) treated with $50 \mathrm{mg} / \mathrm{mL}$ penicillin $\mathrm{G}$ and streptomycin to prevent bacterial growth. For spore isolation, ascomata of Sarea difformis and S. resinae were removed from the resinous substrate and transferred to double cavity glass slides containing a drop of sterile $0.9 \% \mathrm{NaCl}_{2}$ solution. Contaminations were removed under a Carl Zeiss Stemi 2000-C stereomicroscope and the ascomata were transferred to the edge of the second cavity and gently crushed with a flamed needle to liberate the spores. The spores were further diluted in 200-300 $\mu \mathrm{L}$ sterile $0.9 \%$ $\mathrm{NaCl}_{2}$ solution, transferred on the fungal media and incubated at $25-30{ }^{\circ} \mathrm{C}$ for up to $24 \mathrm{mo}$ in the dark.

\section{DNA isolation, amplification and sequencing}

For DNA extraction, ascomata of Sarea difformis and $S$. resinae from environmental samples were cleaned of macroscopical contaminations under a Carl Zeiss Stemi 2000C stereomicroscope, shock frozen with liquid nitrogen and crushed using a glass micromortar and pestle. Cultures of both species isolated from Picea abies were freeze dried (Christ, Alpha 1-4 LDplus, Osterode, Germany) and subsequently pulverized in Eppendorf tubes using plastic pestles. DNA was isolated from the fungal material using the Invisorb Spin Plant Mini Kit (Stratec, Berlin, Germany) by following the manufacturer's protocol, but modified by incubating the samples over night at $52{ }^{\circ} \mathrm{C}$ to ensure the lysis of the fungal cell walls. For phylogenetic analysis, we amplified parts of four protein coding and four ribosomal DNA regions. The protein coding genes represent the RNA polymerase II largest (rpb1) and second largest subunit ( $r p b 2)$, the tsr1 gene, a gene required for rRNA accumulation during biogenesis of the ribosome (Gelperin et al. 2001, Schmitt et al. 2009) and the $m \mathrm{~cm} 7$ gene, a DNA replication licensing factor required for DNA replication initiation and cell proliferation (Moir et al. 1982, Kearsey \& Labib 1998). Ribosomal DNA regions include the small and large nuclear ribosomal subunit (18S rDNA and 28S rDNA respectively), the mitochondrial small ribosomal subunit (mtSSU) as well as the nuclear internal transcribed spacer region (ITS). DNA regions were isolated and amplified from in vitro cultures of Sarea difformis and S. resinae in order to exclude the amplification of DNA from potential contaminates of environmental samples. The nuclear ITS regions of the cultures and environmental samples were compared to make sure that the cultures correspond to the correct environmental sample.

Polymerase chain reaction (PCR) was conducted using Taq DNA polymerase (Promega, Madison, WI) by following the manufacturer's recommendations. Fungal specific primers and PCR conditions used to amplify the gene regions for phylogenetic analysis of this study are provided in Table S2. PCR products were purified using $\mathrm{MSB}^{\circledR}$ Spin PCRapace (Invitek, Berlin, Germany) and sequenced in both directions with a MegaBACE 1000 automated sequencing machine and DYEnamic ET Terminator Cycle Sequencing Kit (Amersham Biosciences, Little Chalfont, UK). Sequences were assembled and edited with BioEdit v. 5.0.9 (Hall 1999).

\section{Reference data sets}

We combined the new ribosomal and protein coding sequences with data from the National Center for Biotechnology Information (NCBI). In total, seven marker sequences were used for the phylogenetic analyses. Since few tsr 1 sequences are available in GenBank we excluded the new, high quality tsr 1 sequences from our phylogenetic analyses in order to avoid a high percentage of missing data in any of the included gene/DNA regions. Accession numbers for all sequences used for the molecular analyses are provided in Table S1.

Three different taxon samplings were assembled:

1. Trapeliales/Helotiales: To assess whether or not the morphological similarities of Sarea and Trapeliales can be substantiated with molecular data we assembled a data set including members of the Trapeliales (Lecanoromycetes) and Helotiales (Leotiomycetes). Additionally, we included representatives of the recently proposed classes Xylonomycetes and Candelariomycetes because in our preliminary analyses (data not shown) included representatives of these two classes often grouped with Sarea when additional Pezizomycotina classes were included in the phylogenetic analyses. The operculate ascomycetes Peziza arvernensis and $P$. varia were used as outgroup. The representative dataset consists of 66 taxa with a total 1295 base pairs of which 449 represent variable sites from the ITS region and 846 sites from the nucLSU. In addition to the sequences of Sarea difformis and S. resinae that we generated in this study, we incorporated some available ITS and nucLSU sequences from GenBank.

2. Lecanoromycetes: To assess whether or not the current (morphological) classification of Sarea in Lecanoromycetes can be confirmed with molecular data we assembled a taxon sampling which broadly corresponds to the well-balanced dataset by Prieto et al. (2013). The dataset comprises 96 taxa and includes 3862 variable sites from four ribosomal (ITS, nucSSU, mtSSU, nucLSU) and two protein coding (mcm7, rpb1) sequences.

3. Pezizomycotina: To place Sarea within Pezizomycotina we assembled a taxon sampling including representatives of all major ascomycete classes except Laboulbeniomycetes, Xylobotryomycetes and Coniocybomycetes because preliminary analyses (data not shown) have shown that these classes are unlikely to be closely related to Sarea. Many of the implemented genes were compiled in a previous study by James et al. (2006). The dataset consists of 103 taxa including 160 base pairs of the ITS region, 916 sites from the small ribosomal subunit (nucSSU), 1057 sites from the large ribosomal subunit (nucLSU), and 900 sites from the rpb2 gene. All reference data sets are available via Treebase http://purl.org/phylo/treebase/phylows/study/TB2:S25817. 


\section{Phylogenetic analyses}

Phylogenetic hypotheses were calculated with the three most current approaches: Bayesian Inference, Maximum Likelihood and Maximum Parsimony. All analyses were performed on the CIPRES Science Gateway v. 3.3 (Miller et al. 2010). For each dataset, included genes were aligned separately by using MAFFT v. 6 (Katoh \& Toh 2008) sometimes with subsequent manual adjustment to minimize the number of possible false homologies using BioEdit v. 5.0.9. (Hall 1999) and SeaView v. 4 (Gouy et al. 2010). Unalignable regions and introns were excluded by using the mask function in BioEdit v. 5.0.9. For each dataset, genes were combined in a super matrix using BioEdit v. 5.0.9.

Maximum Likelihood search for the most likely tree was accomplished using RAxML VI-HPC (Stamatakis 2006, Stamatakis et al. 2008) by applying a GTR model of molecular evolution, $1000 \mathrm{ML}$ bootstrap replicates and the Gamma model of rate heterogeneity by letting RAxML optimize individual $\alpha$-shape parameters and base frequencies for 6 separate gene partitions.

Maximum parsimony (MP) was performed using PAUP v. 4.0 b10 (Swofford 1991, 2002) by treating gaps as missing characters, and by applying 1000 random addition sequences (RAS), TBR (tree bisection reconnection) branch-swapping and MULTREES option. To assess statistical support of the clades, non-parametric bootstrapping (Felsenstein 1985) was performed with heuristic searches.

Bayesian analyses were performed using Markov Chain Monte Carlo (MCMC) in MrBayes v. 3.1.2 (Ronquist \& Huelsenbeck 2003). Best fitting substitution models for each gene were chosen separately from seven substitution schemes included in the software package jModeltest v. 2.1.1 (Darriba et al. 2012), and models were chosen according to the Bayesian information criterion (BIC, Schwarz 1978).

Analyses were run using four chains for 5-10 $\mathrm{M}$ generations each, sampling parameters every 500 to 1000 generations. Average standard deviations of split frequency (ASDSF) lower than 0.01 were interpreted as indicative of independent MCMC convergence.

\section{RESULTS}

\section{Phylogenetic analyses}

The phylogenetic tree obtained from the Trapeliales/Helotiales data (Fig. 2) displays well-supported clades of Sarea, Trapeliales, Helotiales, Candelariomycetes and Xylonomycetes from the Bayesian, Maximum Likelihood and Maximum Parsimony analyses. Xylobotryomycetes were placed as a sister clade to the remaining classes included in this taxon set (data not shown), which means that a relationship with Sarea is not likely. We therefore excluded Xylobotryomycetes in our further analysis. Both Bayesian and Maximum Likelihood approaches place Sarea as second order sister group to Lecanoromycetes with low node support ( $35 \mathrm{ML}-\mathrm{BS}$ and $61 \mathrm{PP}$ ). In each of the three applied methods Sarea species clustered in a well-supported clade (84 ML-BS, 99 PP, 77 MP-BS) and S. difformis (89 ML-BS, 100 PP, 89 MP-BS) and S. resinae (100 ML-BS, 100 PP, 100 MP-BS) build well-supported groups in this clade.
The phylogenetic hypothesis resulting from the six-gene Lecanoromycetes dataset is shown in Fig. 3. The topology of the resulting phylogeny is generally congruent with the analysis of Prieto et al. (2013) and members of currently defined Pezizomycotina classes group in well-supported clades. With three methods (Bayesian, MP and MB) Sarea was placed outside the Lecanoromycetes, but was placed inside the "Leotiomyceta" with unanimous support (99 ML-BS, 100 PP, 91 MP-BS). Maximum Parsimony analysis did not resolve relationships between the classes of Pezizomycotina and relationships between members of Lecanoromycetes were only partly resolved. Bayesian analysis grouped Sarea as sister group o to the clade including Dothideomycetes-Arthoniomycetes and Leotiomycetes-Sordariomycetes with low support (56 PP), but Maximum Likelihood analysis grouped Sarea as sister group of the Coniocybomycetes-Lichinomycetes clade with only very low node support (15 ML-BS).

The phylogenetic hypothesis obtained from our fourgene dataset of Pezizomycotina is shown in Fig. 4. With some exceptions, the topology of the phylogenetic tree broadly corresponds to other large-scale phylogenies of Ascomycota (e.g. Reeb et al. 2004, James et al. 2006, Schoch et al. 2009a, b, Beimforde et al. 2014). In our analysis Xylonomycetes forms two separate groups with Symbiotaphrina placed in the clade also including Candelariomycetes and the here-proposed new class Sareomycetes. However, these results are not congruent with the phylogenomic study of Gazis et al. (2016) which indicate that Symbiotaphrinales represent the sister clade to Xylonomycetales. Otherwise, members of currently defined Pezizomycotina classes group in well-supported clades and show relationships between the major classes of ascomycetes that have been described in other studies, such as Arthoniomycetes-Dothideomycetes, LeotiomycetesSordariomycetes and Lecanoromycetes-Eurotiomycetes. Maximum Parsimony did not resolve the relationships between the Pezizomycotina classes, but both Bayesian Inference and Maximum Likelihood placed Sarea in a clade also including Geoglossomycetes, Candelariomycetes and Xylonomycetes. This group, however, is only indicated by low node support (26 ML-BS, 89 PP).

\section{Taxonomy}

Justified by the distinct phylogenetic position of Sarea from other ascomycetes in our multilocus gene calculations and by the unique combination of ecological and morphological characteristics of the fungal group, we here propose a novel class, order, and family in the Ascomycota to accommodate the genus Sarea: Sareomycetes, Sareales and Sareaceae cl., ord. et fam. nov.

Sareomycetes Beimforde, A.R. Schmidt, Rikkinen \& J.K. Mitch., cl. nov. MycoBank MB831369.

Type order: Sareales Beimforde, A.R. Schmidt, Rikkinen \& J.K. Mitch., ord. nov. MycoBank MB831372.

Type family: Sareaceae Beimforde, A.R. Schmidt, Rikkinen \& J.K. Mitch., fam. nov. MycoBank MB831373.

Type genus: Sarea Fr., Systema Orbis Vegetabilis 1: 86. 1825. 
Beimforde et al.

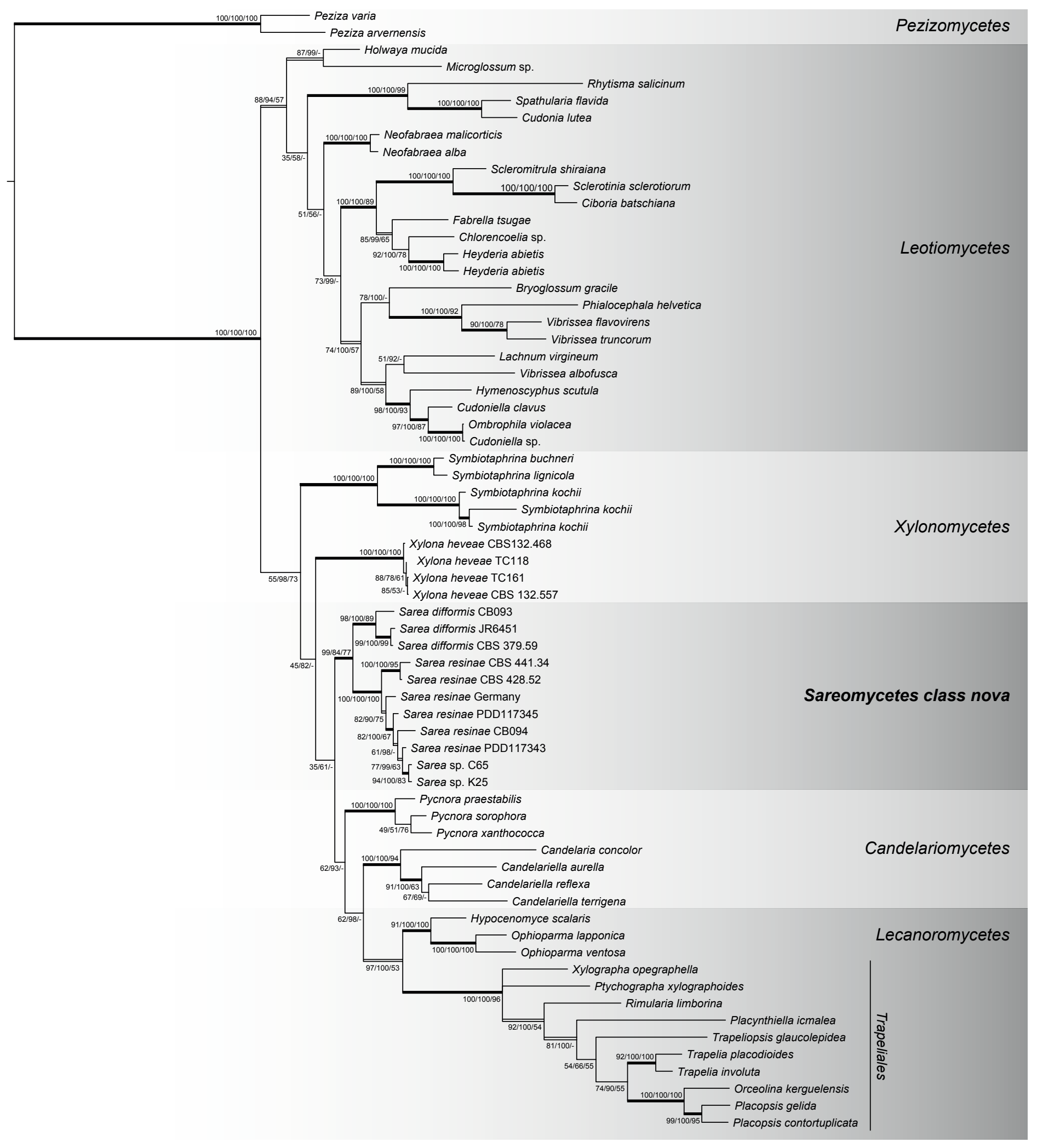

0.04

Fig. 2. Phylogenetic relationships of Sarea, Trapeliales and Helotiales based on two ribosomal genes (ITS, nucLSU) obtained from Bayesian, Maximum Likelihood and Maximum Parsimony (MP) analysis. Posterior Probabilities (PP), ML- and MP-Bootstraps are represented by the first, second and third numbers associated with internodes. Branches in bold indicate PP $\geq 95 \%$, and both ML and MP bootstrap values $\geq 70 \%$. Double lined branches indicate significant support obtained by two out of the three analyses. Scale = number of substitutions per site.

Fig. 3. Phylogenetic relationship of Sarea and Lecanoromycetes based on six genes (ITS, mtSSU, nucSSU, nucLSU, mcm7, rpb1) obtained from Bayesian, Maximum Likelihood and Maximum Parsimony (MP) analysis. Taxon sampling broadly corresponds to the data set by Prieto et al. (2013). Posterior Probabilities (PP), ML- and MP-Bootstraps are represented by the first, second and third numbers associated with internodes. Branches in bold indicate PP $\geq 95 \%$, and both ML and MP bootstrap values $\geq 70 \%$. Double lined branches indicate significant support obtained by two out of the three analyses. Scale $=$ number of substitutions per site. 
Pyronema domesticum

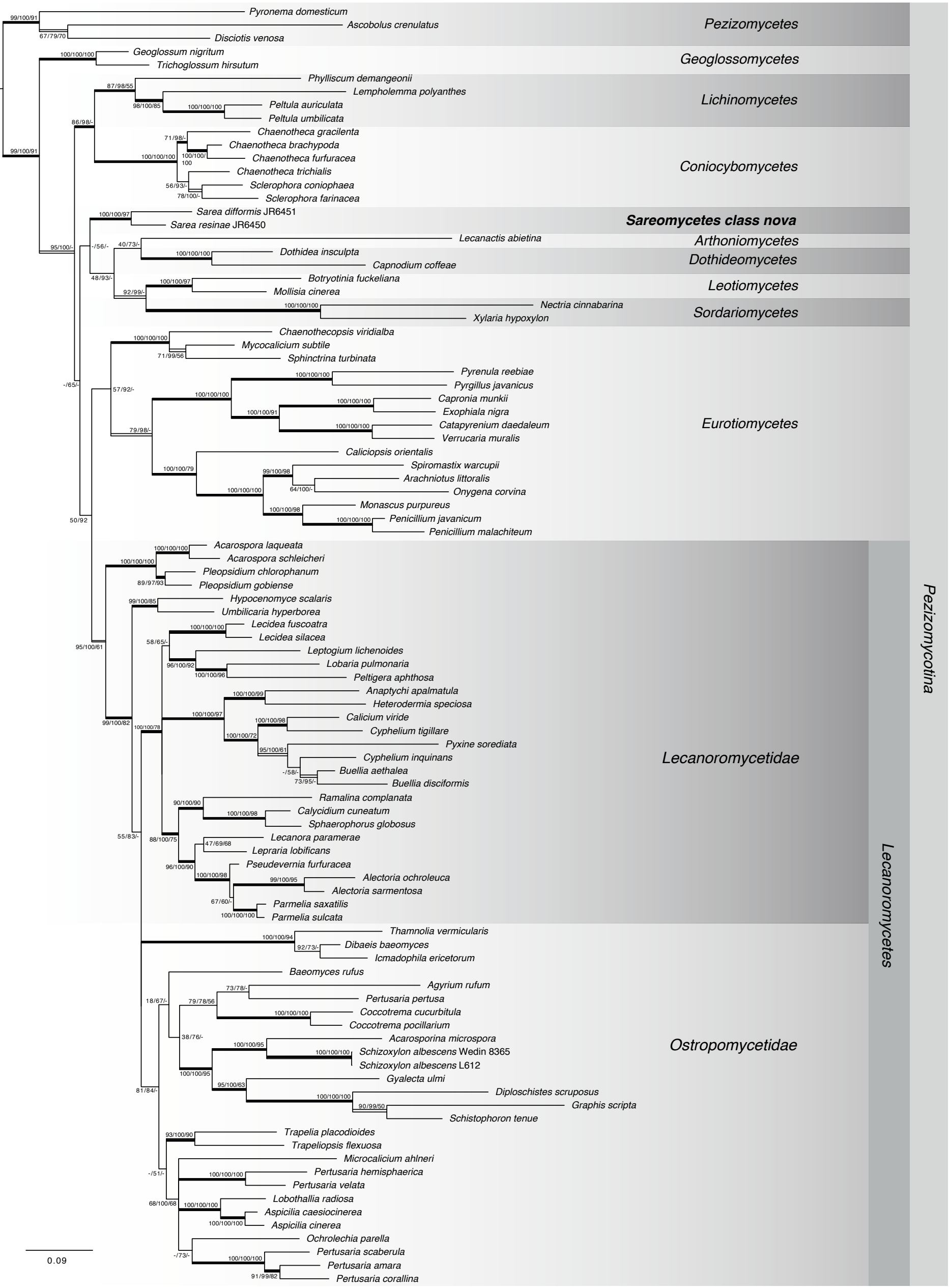




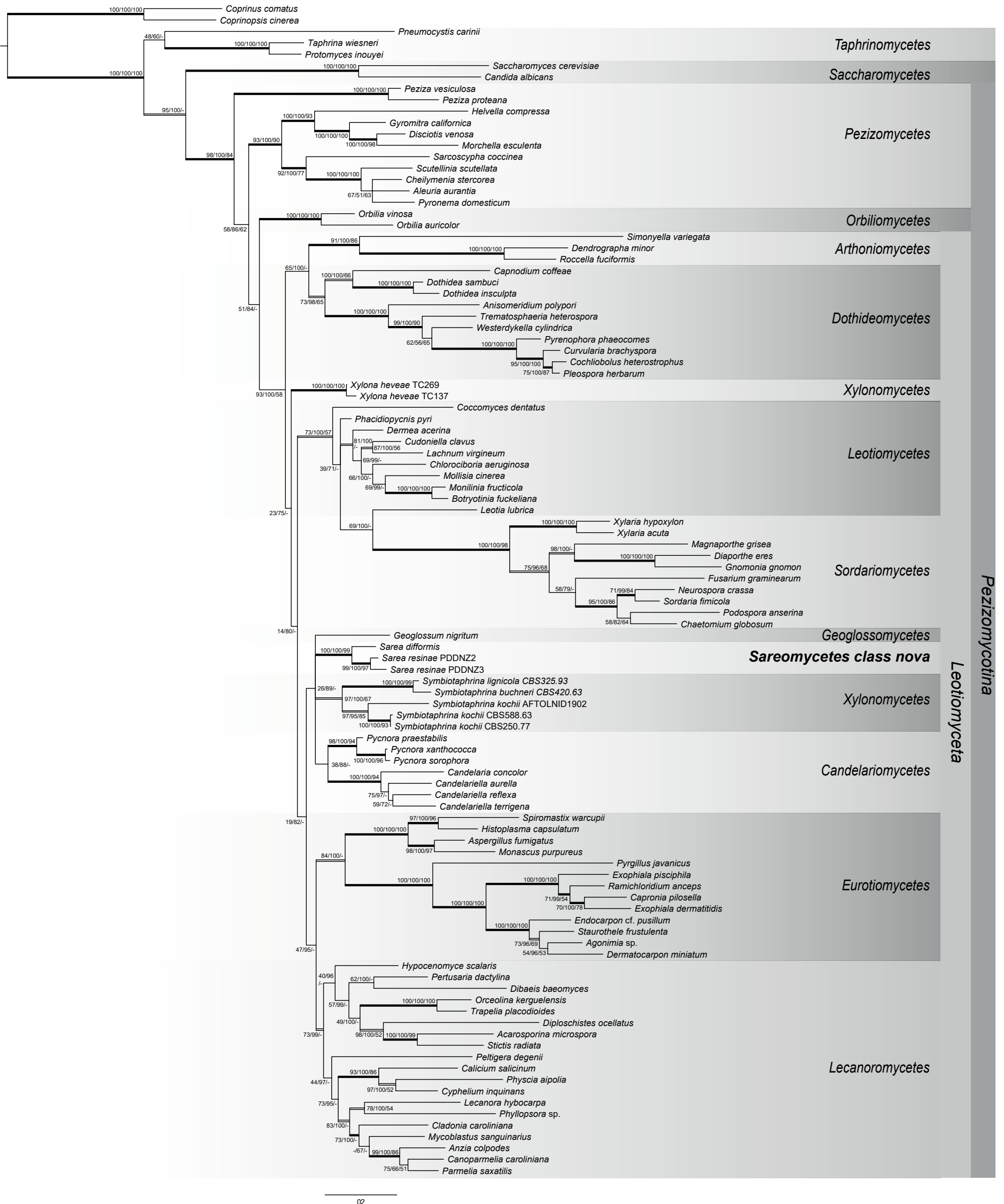

Fig. 4. Phylogenetic relationship of Pezizomycotina based on four genes (ITS, nucSSU, nucLSU, rpb2) obtained from Bayesian, Maximum Likelihood and Maximum Parsimony (MP) analysis. Posterior Probabilities (PP), ML- and MP-Bootstraps are represented by the first, second and third numbers associated with internodes. Branches in bold indicate PP $\geq 95 \%$, and both $\mathrm{ML}$ and MP bootstrap values $\geq 70 \%$. Double lined branches indicate significant support obtained by two out of the three analyses. Scale = number of substitutions per site. 
Type species: Sarea difformis (Fr.) Fr., Elenchus Fungorum 2: 14. 1828. (lectotype)

Sanctioned name: Peziza difformis Fr., Systema Mycologicum 2: 151. 1822.

Type specimen: Rehm's Ascomyceten No. 577, Royal Botanical Garden, Kew, England UK. (neotype)

Etymology: The name of the class, order, and family are derived from the generic name of the type genus, Sarea Fr., Systema Orbis Vegetabilis 1: 86 (1825).

The class, order, and family are based on the same description below:

Multispored, non-lichenized ascomycetes with resinicolous ecology, ascomata apothecial, scattered, formed exclusively on conifer resin, ascohymenial, sessile to short stipitate, pale to deep orange or black, the pigment localized at least in granules in the epithecial layer and marginal extracellular material as well as in oily inclusions in the interior tissues or in patches in the extracellular matrix, fleshy and gelatinous when fresh, becoming coriaceous when dry; excipulum paraplectenchymatous, composed of radiating hyphae immersed in a gel; subhymenium gelatinous, of interwoven hyphae forming a textura intricata, hyaline to brownish or coloured by intracellular pigments. Hymenial elements sometimes lightly bluing in $\mathrm{KOH}$. Paraphyses numerous, often containing numerous oily inclusions, pigmented or not, filiform; septate, mainly unbranched but sometimes anastomosing and often becoming forked near the apices; apices slightly swollen and embedded in gel to form an epithecium-like layer. Asci with croziers, multispored, clavate with thick multilayered walls, not fully functionally bitunicate, the outermost layer amorphous and gelatinous, turning blue in IKI and Melzer's reagent with or without pretreatment in $\mathrm{KOH}$, but staining more intensely after pretreatment, the innermost layer forming a thick apical cap pierced by a central pore, lacking a reaction in IKI and Meltzer's with or without $\mathrm{KOH}$ pretreatment. Ascospores numerous, spherical, minute, hyaline, smooth-walled, thin- to thick-walled, aseptate. Asexual morphs pycnidial, arising singly or in small groups, on conifer resin, superficial or immersed, subglobose, more or less concolourous with their sexual morph, walls composed of interwoven plectenchymatous hyphae forming a textura intricata, hyphae gelatinized or not, walls sometimes convoluted and appearing multilocular in section; ostiolate and papillate when young and expanding with age due to extrusion of conidia or opening by breakdown or tearing of the upper wall to form an irregular hole. Conidiophores lining the cavity of the pycnidium, hyaline, short, branched or not and septate at the base, bearing one to three conidiogenous cells. Conidiogenous cells enteroblastic, phialidic, not proliferating or sometimes with one to four short proliferations, lageniform to cylindrical, tapering towards the apex, hyaline, smooth-walled, with a minute collarette and channel but marked periclinal thickening. Conidia abundantly produced, slimy or forming slimy masses, subglobose when mature but somewhat pyriform when young, sometimes slightly angular due to mutual compression, aseptate, hyaline to pale brown, more or less smooth-walled, thin- or thickwalled, more or less isodiametric with the ascospores of the sexual morph, usually containing a single minute guttule not disappearing in $\mathrm{KOH}$.
Notes: The diagnosis above was modified from the generic description of Sarea and the specific descriptions for Sarea resinae and S. difformis published in Hawksworth \& Sherwood (1981). Hawksworth and Sherwood (1981) also discussed the nomenclatural situation of Sarea in extraordinary detail. As no type species was designated for Sarea by Fries (1822, 1825, 1828), Kuntze (1898) lectotypified Sarea by Peziza difformis. Neither Kuntze (1898) nor Fries $(1822,1828)$ mentioned any locality of the described specimens and no original material is known to exist, and therefore Hawksworth \& Sherwood (1981) selected a neotype for the name Peziza difformis, which is stored in the Royal Botanical Garden, Kew, England UK. Hawksworth \& Sherwood (1981) also designated a lectotype for Sarea resinae (Peziza resinae), which is stored in the Acharius Herbarium in the University of Helsinki Herbarium in Helsinki.

Specimens examined: Sarea difformis CB093 (H), Sarea difformis JR6451 $(\mathrm{H})$, Sarea resinae CB094 (H), Sarea resinae JR6450 (H), Sarea resinae PDD117343, Sarea resinae PDD117345. Information of the substrate, collection locality, voucher number and collection where the specimens are deposited is listed in Table 1.

\section{DISCUSSION}

\section{Phylogeny}

According to our phylogenetic results (Figs 2-4) Sarea does not belong in Trapeliales (Lecanoromycetes) - as the current taxonomic classification suggests (Lumbsch \& Huhndorf 2010, Hodkinson \& Lendemer 2011) - and cannot be classified within Lecanoromycetes. All of our analyses placed Sarea in the clade of inoperculate euascomycetes which corresponds to the rankless "Leotiomyceta" (Eriksson \& Winka 1997) with unanimous support, but none satisfactorily assigned it to any of the existing classes in "Leotiomyceta".

Based on morphological similarities, previous studies placed the two Sarea species in various genera of Lecanoromycetes, for instance Biatorella within Acarosporaceae, Biatora in Ramalinaceae, or Lecidea within Lecideaceae. Nannfeldt (1932) placed both as species of Tromera within Lecanorales due to their thick ascus walls and the presence of an epithecium and amyloid reaction in the hymenium. Hawksworth \& Sherwood (1981) also assigned Sarea to Lecanoromycetes because it resembles Agyrium rufum (Agyriaceae) in ascus structure, pigmentation and excipular structure.

Like Sarea, most genera in which Sarea was previously classified also include species with polyspored asci. True polyspory (= meiosis followed by several mitoses generating more than 100 spores, Gueidan et al. 2015) occurs in many other species in Lecanoromycetes. In the past, Acarosporaceae was characterized by its true polyspory (Gueidan et al. 2015), but molecular studies revealed that lichenized polysporous species do not form a monophyletic group and that polysporous asci evolved several times within lichenized species (Reeb et al. 2004, Aptroot \& Schumm 2012). However, true polyspory has also evolved in non-lichenized genera such as Deltopyxis (Baral \& Marson 2012), Podospora (Mirza \& Cain 1969), Thelebolus (de Hoog et al. 2005) and Tromeropsis. The last was shown to be congeneric to Symbiotaphrina in Xylonomycetes (Baral et al. 2018). It is not known if the polyspory is linked to ecological environmental conditions, but it is noticeable that many 
polyspored species occur in xeric habitats (Sherwood 1981).

The polyspored asci, apothecial ascomata and the nonlichenized resinicolous ecology are fundamental characters of all Sarea species. Claussenomyces olivaceus also possesses polyspored asci while occurring on resin. However, in contrast to Sarea, its ascospores (ascoconidia) arise from septate primary ascospores (Medardi 2007).

Another feature that Hawksworth \& Sherwood (1981) did not mention is the distribution of pigments in Sarea resinae. The pigment may be located in the excipulum, subhymenium, hymenium, and apothecial surface, and can vary in intensity to the point of being absent in some structures between clades of S. resinae. Additionally, the excipular cells may vary in tightness between Sarea clades and differences in stipe length, presence and amount of granular material at the margins of the cups appear, depth of hymenium or thickness of epithecium seem to be other variable features between Sarea clades. However, these features are variable also based on environmental conditions and developmental stages.

Previous classifications of Ascomycota emphasized the morphology and development of the ascoma, and especially similar ascus structures and the mechanisms of spore release. Since then, molecular methods have revolutionized phylogenetic systematics of fungi (e.g. Lutzoni et al. 2004, Hibbett et al. 2007, Schoch et al. 2009a, Miadlikowska et al. 2006, Prieto et al. 2013). Lumbsch et al. (2007) pointed out that the ascus types in Trapeliaceae and Agyriaceae are phylogenetically misleading, since the ascus type of Agyrium agrees with those of Trapeliaceae, but the morphological similarities are inconsistent with molecular analyses. They excluded Sarea from their phylogenetic study since molecular data rather suggested a placement outside Ostropomycetidae.

In molecular approaches, potential sources of error include undetected (e.g. homoplasy, Goloboff et al. 2008) or wrongly inferred substitutions (e.g. long branch attraction, Bergsten 2005), polymorphism and gene specific evolution. Because most species have not been sequenced and/or even discovered to date (Blackwell 2011), taxon sampling biases also have to be considered (e.g. Cusimano et al. 2012). Often new gene sequences, such as the tsr 1 genes of Sarea generated in this study, are difficult to include in phylogenetic analyses, because they are underrepresented in GenBank. However, in the future more use could be made from genome extractions provided that the quality of the genes can be guaranteed. In any case, morphological and physiological traits provide additional diagnostic and biological information and should not be disregarded in current classifications (e.g. Hibbett et al. 2007).

We provide the first phylogenetic study of Sarea that includes molecular data from protein coding and ribosomal gene regions. Our results are consistent with previous molecular studies in that Sarea was placed within the clade of inoperculate euascomycetes, but could not be assigned to any of the currently defined classes in Ascomycota. Giraldo et al. (2014) reported affiliations of Sarea with Lecanoromycetes, but this was only based on data from a single gene (nucLSU) and the placement had no statistical support. Only a few other studies (Lutzoni et al. 2004, Reeb et al. 2004, Wang et al. 2006, 2009, Miadlikowska et al. 2014) supported the placement of Sarea outside Lecanoromycetes and an affiliation of Sarea with the Leotiomycetes was found by Reeb et al. (2004) and Wang et al. (2006). Here we cannot confirm an affiliation of Sarea with the
Leotiomycetes (Figs 2-4), nor can we suggest a well-supported affiliation to any other class within "Leotiomyceta". However, in previous phylogenetic studies (Reeb et al. 2004, Wang et al. 2006) as well as our own, relationships between Sarea and other Pezizomycotina classes were indicated by only low node support and we therefore cannot assume a closer relationship of these taxon groups. It is rather the case that taxon groups of uncertain affiliations (including Sarea) in the assembled taxon sets cluster together (long branch attraction, Bergsten 2005, 1978) and it is likely that the placement of Sarea as sister taxon to Leotiomycetes in previous studies is just coincidence.

Our phylogenetic results (Figs 2-4) show that Sarea does not belong to Lecanoromycetes as currently assigned. Based on the information from the seven DNA regions, Sarea cannot be assigned to any of the classes of Pezizomycotina, but forms an isolated and highly supported lineage within "Leotiomyceta". We therefore propose to recognize this group formally as the new class, order, and family Sareomycetes, Sareales and Sareaceae.

\section{ACKNOWLEDGEMENTS}

We thank William G. Lee (Landcare Research, Dunedin) and Adrienne Stanton (New Zealand Fungarium (PDD) Landcare Research, Auckland) for providing and hosting specimens of Sarea resinae from New Zealand, and Uwe Kaulfuß (Göttingen) for commenting on the manuscript. The authors are grateful to the editor Pedro W. Crous and two anonymous reviewers for constructive comments that improved the manuscript.

Conflict of interest: The authors declare that there is no conflict of interest.

\section{REFERENCES}

Adams AS, Aylward FO, Adams SM, et al. (2013). Mountain pine beetles colonizing historical and naïve host trees are associated with a bacterial community highly enriched in genes contributing to terpene metabolism. Applied and Environmental Microbiology 79: 3468-3475.

Aptroot A, Schumm F (2012). The genus Melanophloea, an example of convergent evolution towards polyspory. The Lichenologist 44: 501-509.

Ayers TT (1941). Biatorella resinae: The Perfect Stage of Zythia resinae. Mycologia 33: 130-135.

Baral HO, Marson G (2012). Deltopyxis triangulispora gen. et sp. nov., a polysporous Tromeropsis-like discomycete of unclear relationship. Andrias 19: 175-183.

Baral HO, Weber E, Marson G, et al. (2018). A new connection between wood saprobism and beetle endosymbiosis: the rarely reported saprobic discomycete Tromeropsis is congeneric with the symbiotic yeast Symbiotaphrina (Symbiotaphrinales, Xylonomycetes) and two asexual morphs misplaced in Hyphozyma. Mycological Progress 17: 215-254.

Baranyay JA (1966). Fungi from dwarf mistletoe infections in western hemlock. Canadian Journal of Botany 44: 597-604.

Bartkowiak ME, Bennett JP (2015). Floristic study of lichens in Portage County, Wisconsin. Evansia 32: 176-188.

Bazhina EV, Aminev PI (2012). Effect of Biatorella canker on pollen viability and variation of shoot characters in Scots pine. Russian Journal of Ecology 43: 101-106.

Bednarek P, Osbourn A (2009). Plant-microbe interactions: chemical 
diversity in plant defense. Science 324: 746-747.

Beimforde C, Feldberg K, Nylinder S, et al. (2014). Estimating the Phanerozoic history of the Ascomycota lineages: combining fossil and molecular data. Molecular Phylogenetics and Evolution 77: 307-319.

Berbee ML, Taylor JW (1992). Detecting morphological convergence in true fungi using 18S rRNA gene sequence. BioSystems 28: 117-125.

Bergsten J (2005). A review of long-branch attraction. Cladistics 21: 163-193.

Blackwell M (2011). The Fungi: 1, 2, 3 ... 5.1 Million Species? American Journal of Botany 98: 426-438.

Cappelletti C (1924). Studi su la vegetazione resinicola. Annali di Botanica 16: 253-297.

Conners IL (1967). An annotated index of plant diseases in Canada, and fungi recorded on plants in Alaska, Canada and Greenland. Queen's Printers, Ottawa.

Crous PW, Wingfield MJ, Lombard L, et al. (2019). Fungal Planet description sheets: 951-1041. Persoonia 43: 223-425.

Cusimano N, Stadler T, Renner SS (2012). A new method for handling missing species in diversification analysis applicable to randomly or non-randomly sampled phylogenies. Systematic Biology 61: 785792.

Czyżewska K, Motiejūnaitė J, Cieśliński S (2005). New and noteworthy species of lichens and allied fungi from north-eastern Poland. Acta Mycologica 40: 277-291.

Darriba D, Taboada GL, Doallo R, et al. (2012). JModelTest 2: more models, new heuristics and parallel computing. Nature Methods $\mathbf{9}$ : 772.

de Hoog GS, Göttlich E, Platas G, et al. (2005). Evolution, taxonomy and ecology of the genus Thelebolus in Antarctica. Studies in Mycology 51: 33-76.

Eriksson OE, Winka K (1997). Supraordinal taxa of the Ascomycota. Myconet 1: 1-16.

Etayo J (1996). Contribution to the lichen flora of the Canary Islands. II. Epiphytic lichens from La Palma. Österreichische Zeitschrift für Pilzkunde 5: 149-159.

Farrell BD, Dussourd DE, Mitter C (1991). Escalation of plant defense: Do latex/resin canals spur plant diversification? American Naturalist 138: 881-900.

Felsenstein J (1985). Confidence limits on phylogenies: an approach using the bootstrap. Evolution 39: 783-791.

Fink B (1935). The lichen flora of the United States. University of Michigan Press, Ann Arbor.

Fries EM (1822). Systema Mycologicum, Sistens Fungorum Ordines, Genera et Species, Huc Usque Cognitas, Quas Ad Normam Methodi Naturalis Determinavit, Disposuit Atque Descripsit. Voluminis II Sectio I. Ex Officina Berlingiana. Lundæ.

Fries EM (1825). Systema Orbis Vegetabilis: Primas Lineas Novæ Constructionis Periclitatur. Pars I. Plantæ Homonemeæ. E Typographia Academica. Lundæ.

Fries EM (1828). Elenchus fungorum, sistens commentarium in Systema mycologicum. Vol.1. E. Mauritius, Greifswald.

Funk A (1981). Parasitic microfungi of western trees. Information Report BC-X-222. Environment Canada, Canadian Forestry Service. Pacific Forest Research Centre, Victoria, BC.

Gadgil PD, Dick M (1999). Fungi Silvicolae Novaezelandiae: 1. New Zealand Journal of Forestry Science 29: 428-439.

Gazis R, Kuo A, Riley R, et al. (2016). The genome of Xylona heveae provides a window into fungal endophytism. Fungal Biology 120 : 26-42.

Garrido-Benavent I (2015). Contribución al conocimiento del género Sarea Fr. (Ascomycota, Incertae sedis) en la Península Ibérica.
Sociedad Micológica Errotari 12: 42-51.

Gelperin D, Horton L, Beckman J, et al. (2001). Bms1p, a novel GTPbinding protein, and the related Tsr1p are required for distinct steps of $40 \mathrm{~S}$ ribosome biogenesis in yeast. Rna-a Publication of the Rna Society 7: 1268-1283.

Gershenzon J, Dudareva N (2007). The function of terpene natural products in the natural world. Nature Chemical Biology 3: 408-414.

Giordano L, Gonthier P, Varese G, et al. (2009). Mycobiota inhabiting sapwood of healthy and declining Scots pine (Pinus sylvestris L.) trees in the Alps. Fungal Diversity 38: 69-83.

Giraldo A, Gené J, Sutton DA, et al. (2014). Phylogenetic circumscription of Arthrographis (Eremomycetaceae, Dothideomycetes). Persoonia 32: 102-114.

Goloboff PA, Carpenter JM, Salvador Ariasc J, et al. (2008). Weighting against homoplasy improves phylogenetic analysis of morphological data sets. Cladistics 24: 758-773.

Gouy M, Guindon S, Gascuel O (2010). Seaview version 4: a multiplatform graphical user interface for sequence alignment and phylogenetic tree building. Molecular Biology and Evolution 27: 221-224.

Gueidan C, Hill DJ, Miadlikowska J, et al. (2015). Pezizomycotina: Lecanoromycetes. In: The Mycota. Vol. 7B. $2^{\text {nd }}$ edition. Systematics and Evolution (McLaughlin DJ, Spatafora JW, eds). Springer-Verlag, Berlin Heidelberg, Germany: 89-121.

Hall TA (1999). BioEdit: a user-friendly biological sequence alignment editor and analysis program for Windows 95/98/NT. Nucleic Acids Symposium Series 41: 95-98.

Hasse HE (1898). Lichens of Southern California. 2nd edn. B. R. Baumgardt \& Co, Los Angeles.

Hasse HE (1908). Lichens collected in the Tehachepi Mountains, California, June, 1907. The Bryologist 11: 55.

Hawksworth DL, Sherwood MA (1981). A reassessment of three widespread discomycetes. Canadian Journal of Botany 59: 357-372.

Hibbett DS, Binder M, Bischoff JF, et al. (2007). A higher-level phylogenetic classification of the Fungi. Mycological Research 111: 509-547.

Himelbrant DE (2016). The lichens and allied fungi from the Leningrad Region and Saint Petersburg in the lichen herbarium of the University of Tartu. Folia Cryptogamica Estonica 53: 35-42.

Hodkinson BP, Lendemer JC (2011). The orders of Ostropomycetidae (Lecanoromycetes, Ascomycota): recognition of Sarrameanales and Trapeliales with a request to retain Pertusariales over Agyriales. Phytologia 93: 407-412.

Howe GA, Schaller A (2008). Direct defense in plants and their induction by wounding and insect herbivores. In: Schaller A. (ed), Induced Plant Resistance to Herbivory. Springer, Germany: 7-29.

James TY, Kauff F, Schoch CL, et al. (2006). Reconstructing the early evolution of Fungi using a six-gene phylogeny. Nature 443: 818822.

Katoh K, Toh H (2008). Recent developments in the MAFFT multiple sequence alignment program. Briefings in Bioinformatics 92: 86-98.

Kearsey SE, Labib K (1998). MCM proteins: evolution, properties, and role in DNA replication. Biochimica et Biophysica Acta 1398: 113136.

Kobayashi T, Zhao JZ (1989). Notes on diseases of woody plants and their causal fungi in Heilongjiang province, China, 1. Transactions of the Mycological Society of Japan 30: 277-293.

Koerber GW (1865). Parerga lichenologica: Ergänzungen zum Systema lichenum Germaniae. Verlag von Eduard Trewendt. Breslau.

Koukol O, Kolařík M, Kolářová Z, et al. (2012). Diversity of foliar endophytes in wind-fallen Picea abies trees. Fungal Diversity 54: 69-77.

Kowalski T, Kehr RD (1992). Endophytic fungal colonization of branch 
bases in several forest tree species. Sydowia 44: 137-168.

Kujala V (1950). Über die Kleinpilze der Koniferen in Finnland. Ascomycetes, Fungi Imperfecti, Uredinales. Metsätieteellisen Tutkimuslaitoksen Julkaisuja 38: 1-121.

Kukwa M, Schiefelbein U, Czarnota P, et al. (2008). Notes on some noteworthy lichens and allied fungi found in the Białowieża Primeval Forest in Poland. Bryonora 41: 1-11.

Kuntze O (1898). Revisio Generum Plantarum. Pars III(III). Arthur Felix. Leipzig.

Kuz'michev EP, Sokolova ES, Kulikova EG (2001). Common fungal diseases of Russian forests. General Technical Report NE-279. USDA Forest Service. Newtown Square, PA.

Kuznetsova ES, Kataeva OA, Himelbrant DE, et al. (2016). Lichens and allied fungi of the Ragusha River Protected Area (Leningrad Region, Russia). Folia Cryptogamica Estonica 53: 71-80.

LoBuglio KF, Pfister DH (2010). Placement of Medeolaria farlowii in the Leotiomycetes, and comments on sampling within the class. Mycological Progress 9: 361-368.

Lõhmus P, Leppik E, Motiejūnaitė J, et al. (2012). Old selectively cut forests can host rich lichen communities - lessons from an exhaustive field survey. Nova Hedwigia 95: 493-515.

Łubek A., Jaroszewicz B (2012). New, rare and noteworthy species of lichens and lichenicolous fungi from Białowieża Forest. Polish Journal of Natural Sciences 27: 275-287.

Lumbsch TH, Schmitt I, Mangold A, et al. (2007). Ascus types are phylogenetically misleading in Trapeliaceae and Agyriaceae (Ostropomycetidae, Ascomycota). Mycological Research 111: 1133-1141.

Lumbsch HT, Huhndorf SM (2010). Myconet Volume 14. Part One. Outline of Ascomycota - 2009. Part Two. Notes on Ascomycete Systematics. Nos. 4751-5113. Fieldiana Life Earth Sciences 1: 1-64.

Lutzoni F, Kauff F, McLaughlin D, et al. (2004). Assembling the fungal tree of life: progress, classification, and evolution of subcellular traits. American Journal of Botany 91: 1446-1480.

Malençon G (1979). Nouvelles contributions a la flore mycologique du Maroc II. Bulletin Trimestriel de la Société Mycologique de France 95: 119-137.

McMullin RT, Lendemer JC (2016). Lichens and Allied Fungi of Awenda Provincial Park, Ontario: Diversity and Conservation Status. The American Midland Naturalist 176: 1-19.

Medardi G (2007). Overview of the genus Claussenomyces and a description of Italian collections. Czech Mycology 59: 101-109.

Miądlikowska J, Kauff F, Hofstetter V, et al. (2006). New insights into classification and evolution of the Lecanoromycetes (Pezizomycotina, Ascomycota) from phylogenetic analyses of three ribosomal RNAand two protein-coding genes. Mycologia 98: 1089-1102.

Miadlikowska J, Kauff F, Högnabba F, et al. (2014). A multigene phylogenetic synthesis for the class Lecanoromycetes (Ascomycota): 1307 fungi representing 1139 infrageneric taxa, 317 genera and 66 families. Molecular Phylogenetics and Evolution 79: 132-168.

Miller MA, Pfeiffer W, Schwartz T (2010). Creating the CIPRES Science Gateway for inference of large phylogenetic trees. In: Institute of Electrical and Electronics Engeneers. Proceedings of the Gateway Computing Environments Workshop (GCE), New Orleans, LA: 1-8.

Mirza JH, Cain RF (1969). Revision of the genus Podospora. Canadian Journal of Botany 47: 1999-2048.

Moir D, Stewart SE, Osmond BC, et al. (1982). Cold-sensitive cell divisioncycle mutants of yeast: Isolation, properties, and pseudoreversion studies. Genetics 100: 547-563.

Motiejūnaitè J (2015). Lichens And Allied Fungi From The Čepkeliai State Nature Reserve (Southern Lithuania). Botanica Lithuanica 21: 3-12. Mudd W (1861). A manual of British lichens. Harrison Penney.
Darlington.

Nannfeldt JA (1932). Studien über die Morphologie und Systematik der nicht-lichenisierten inoperculaten Discomyceten. Nova Acta Regiae Societas Scientiarum Upsaliensis, Ser. IV 8: 1-368.

Nylander W (1866). Lichenes lapponiae orientalis. Notiser ur Sällskapets por Fauna et Flora Fennica Förhandlingar 8: 101-192.

Ohlert A (1870). Zusammenstellung der Lichenen der Provinz Preussen. Druck der Universität-Buch- und Steindruckerei von E. J. Dalkowski, Königsberg.

Petrini O, Carroll G (1981). Endophytic fungi in foliage of some Cupressaceae in Oregon. Canadian Journal of Botany 59: 629-636.

Petrini O, Fisher PJ (1988). A comparative study of fungal endophytes in xylem and whole stem of Pinus sylvestris and Fagus sylvatica. Transactions of the British Mycological Society 91: 233-238.

Prieto M, Baloch E, Tehler A, et al. (2013). Mazaedium evolution in the Ascomycota (Fungi) and the classification of mazaediate groups of formerly unclear relationship. Cladistics 29: 296-308.

Rautio M, Sipponen A, Lohi J, et al. (2011). In vitro fungistatic effects of natural coniferous resin from Norway spruce (Picea abies). European Journal of Clinical Microbiology and Infectious Diseases 31: 1783-1789.

Reeb V, Lutzoni F, Roux C (2004). Contribution of rpb2 to multilocus phylogenetic studies of the euascomycetes (Pezizomycotina, Fungi) with special emphasis on the lichen-forming Acarosporaceae and evolution of polyspory. Molecular Phylogenetics and Evolution 32: 1036-1060.

Rikkinen J (2003). New resinicolous ascomycetes from beaver scars in western North America. Annales Botanici Fennici 40: 443-450.

Rikkinen J, Poinar G (2000). A new species of resinicolous Chaenothecopsis (Mycocaliciaceae, Ascomycota) from 20 million year old Bitterfeld amber, with remarks on the biology of resinicolous fungi. Mycological Research 104: 7-15.

Rikkinen J, Tuovila H, Beimforde C, et al. (2014). Chaenothecopsis neocaledonica sp. nov.: The first resinicolous mycocalicioid fungus from Araucariaceae. Phytotaxa 173: 49-60.

Rikkinen J, Beimforde C, Seyfullah LJ, et al. (2016). Resinogalea humboldtensis gen. et sp. nov., a new resinicolous fungus from $\mathrm{New}$ Caledonia, placed in Bruceomycetaceae fam. nova (Ascomycota). Annales Botanici Fennici 53: 205-215.

Rikkinen J, Schmidt AR (2018). Morphological convergence in forest microfungi provides a proxy for Eocene forest structure. In: Transformative Palaeobotany. Papers to commemorate the life and legacy of Thomas N. Taylor (Krings M, Harper CJ, Cúneo NR, et al., eds). Academic Press, UK: 527-549.

Robertson J (2002). Pygmy Forest Fieldtrip, Mendocino Co., March 16, 2002 and list of Macrolichens of the Pygmy Forest. Bulletin of the California Lichen Society 9: 8-12.

Ronquist F, Huelsenbeck JP (2003). Bayesian phylogenetic inference under mixed models. Bioinformatics 19: 1572-1574.

Safronova IE, Palnikova EN (2010). Correlation between Big Pine Weevil and Biatorella Canker in the Krasnoyarsk Priangarye Pine Saplings. The Bulletin of the Krasnoyarsk State Agrarian University 2010: 74-79.

Safronova IE, Sorokin ND (2013). The pine undergrowth density influence on Biatorella pine canker prevalence. The Bulletin of the Krasnoyarsk State Agrarian University 2013: 91-96.

Sanz-Ros AV, Müller MM, San Martín R, et al. (2015). Fungal endophytic communities on twigs of fast and slow growing Scots pine (Pinus sylvestris L.) in northern Spain. Fungal Biology 119: 870-883.

Schmitt I, Mueller G, Lumbsch HT (2005). Ascoma morphology is homoplaseous and phylogenetically misleading in some pyrenocarpous lichens. Mycologia 97: 362-374. 
Schmitt I, Crespo A, Divakar PK, et al. (2009). New primers for promising single-copy genes in fungal phylogenetics and systematics. Persoonia 23: 35-40.

Schoch CL, Sung GH, López-Giráldez F, et al. (2009a). The Ascomycota Tree of Life: a phylum-wide phylogeny clarifies the origin and evolution of fundamental reproductive and ecological traits. Systematic Biology 58: 224-239.

Schoch CL, Wang Z, Townsend JP, et al. (2009b). Geoglossomycetes cl. nov., Geoglossales ord. nov. and taxa above class rank in the Ascomycota Tree of Life. Persoonia 22: 129-138.

Schwarz G (1978). Estimating the dimension of a model. Annals of Statistics 6: 461-464.

Seifert KA, Hughes SJ, Boulay H, et al. (2007). Taxonomy, nomenclature and phylogeny of three Cladosporium-like hyphomycetes, Sorocybe resinae, Seifertia azaleae and the Hormoconis anamorph of Amorphotheca resinae. Studies in Mycology 58: 235-245.

Seyfullah LJ, Beimforde C, Dal Corso J, et al. (2018). Production and preservation of resins - past and present. Biological Reviews 93: 1684-1714.

Sherwood MA (1981). Convergent evolution in discomycetes from bark and wood. Botanical Journal of the Linnean Society 82: 15-34.

Sipponen A, Laitinen K (2011). Antimicrobial properties of natural coniferous rosin in the European Pharmacopoeia challenge test. Acta Pathologica Microbiologica et Immunologica Scandinavia 119: 720-724.

Smerlis E (1973). Pathogenicity tests of some discomycetes occurring on conifers. Canadian Journal of Forest Research 3: 7-16.

Stamatakis A (2006). RAxML-VI-HPC: maximum likelihood-based phylogenetic analyses with thousands of taxa and mixed models. Bioinformatics 22: 2688-2690.

Stamatakis A, Hoover P, Rougemont J (2008). A fast bootstrapping algorithm for the RAxML Web-Servers. Systematic Biology 57: 758771.

Suto $Y$ (2000). Etiological studies on the resinous stem canker of Chamaecyparis obtusa: A review of studies on the fungi relating to symptom development. The Journal of the Japanese Forestry Society 82: 397-406.

Swofford DL (1991). PAUP: Phylogenetic Analysis Using Parsimony, Version 3.1. Computer program distributed by the Illinois Natural History Survey, Champaign, Illinois.
Swofford DL (2003). PAUP*. Phylogenetic Analysis Using Parsimony (* and Other Methods), v. 4.0b10. Sinauer Associates, MA.

Szymczyk R, Kuwka M, Flakus A, et al. (2014). Lichens and allied nonlichenized fungi on the special area of conservation Natura 2000 "Swajnie" PLH 280046 (Northern Poland). Polish Journal of Natural Sciences 29: 319-336.

Tuovila H (2013). Sticky business - diversity and evolution of Mycocaliciales (Ascomycota) on plant exudates. Publications from the Department of Botany, University of Helsinki, Helsinki.

Tuovila H, Cobbinah JR, Rikkinen J (2011a). Chaenothecopsis khayensis, a new resinicolous calicioid fungus on African mahogany. Mycologia 103: 610-615.

Tuovila H, Larsson P, Rikkinen J (2011b). Three resinicolous North American species of Mycocaliciales in Europe with a re-evaluation of Chaenothecopsis oregana Rikkinen. Karstenia 51: 37-49.

Tuovila H, Rikkinen J, Huhtinen S (2012). Nomenclatural corrections in calicioid fungi. Karstenia 52: 73-4.

Tuovila H, Schmidt AR, Beimforde C, et al. (2013). Stuck in time - a new Chaenothecopsis species with proliferating ascomata from Cunninghamia resin and its fossil ancestors in European amber. Fungal Diversity 58: 199-213.

Wang Z, Johnston PR, Takamatsu S, et al. (2006). Toward a phylogenetic classification of the Leotiomycetes based on rDNA data. Mycologia 98: 1065-1075.

Wang Z, Johnston PR, Yang ZL, et al. (2009). Evolution of reproductive morphology in leaf endophytes. PLOS ONE 4, e4246.

Watson W (1948). List of British fungi parasitic on lichens or which have been included as lichens (or vice versa), with some notes on their characters and distribution. Transactions of the British Mycological Society 31: 305-339.

Wirth $\vee$ (1995). Die Flechten Baden-Württembergs, 2nd ed. Verlag Eugen Ulmer, Stuttgart.

Yatsyna A (2015). Lichens from Manor Parks in Minsk Region (Belarus). Botanica Lithuanica 20: 159-168.

\section{Supplementary Material: http://fuse-journal.org/}

Table S1. GenBank accession numbers and voucher information. Table S2. PCR primers and PCR conditions used in this study. 
Table S1

List of taxa used in this study with GenBank accession numbers and voucher information

\begin{tabular}{|c|c|c|c|c|c|c|c|c|}
\hline & \multirow[t]{2}{*}{\begin{tabular}{|l} 
Collection \\
/Strain number
\end{tabular}} & \multicolumn{7}{|c|}{ GenBank accession number } \\
\hline & & ITS & mtSSU & nuLsu & nussu & RPB1 & RPB2 & MCM7 \\
\hline Acarospora laqueata & $\begin{array}{l}\text { Westberg 10-170 } \\
\text { (S) }\end{array}$ & DQ842014 & DQ991757 & AY640943 & AY640984 & DQ782860 & - & JX000147 \\
\hline Acarospora schleicheri & \begin{tabular}{|l|}
$\begin{array}{l}\text { Obermayer } 2929 \\
\text { (UPS) }\end{array}$ \\
\end{tabular} & HQ650721 & AY584694 & AY640945 & AY640986 & DQ782859 & - & JX000148 \\
\hline $\begin{array}{l}\text { Acarosporina } \\
\text { microspora }\end{array}$ & & DQ782834 & AY584612 & AY584643 & AY584667 & DQ782818 & AY584682 & - \\
\hline Agonimia sp. & & - & - & DQ782913 & DQ782885 & & DQ782874 & \\
\hline Agyrium rufum & \begin{tabular}{|l|} 
Wedin 7931 \\
(UPS)
\end{tabular} & JX000097 & EF581823 & EF581826 & - & EF581822 & - & GU980988 \\
\hline Alectoria ochroleuca & & HQ650597 & DQ986785 & DQ986801 & DQ983483 & DQ986857 & - & - \\
\hline Alectoria sarmentosa & & DQ979998 & - & DQ899291 & AF140233 & DQ899290 & - & JN009675 \\
\hline Anaptychia palmatula & & HQ650702 & DQ912286 & DQ883801 & DQ883792 & DQ883744 & - & - \\
\hline Anisomeridium polypori & & DQ782838 & - & DQ782906 & DQ782877 & - & DQ782864 & - \\
\hline Anzia colpodes & & DQ980000 & - & DQ923651 & DQ923622 & - & - & - \\
\hline Arachniotus littoralis & & AB566293 & FJ225784 & FJ358272 & FJ358340 & FJ358404 & - & - \\
\hline Ascobolus crenulatus & F9477 (S) & DQ491504 & - & AY544678 & AY544721 & DQ471132 & - & JX000149 \\
\hline Aspergillus fumigatus & & FJ878717 & - & AY660917 & AB008401 & - & XM741647 & \\
\hline Aspicilia caesiocinerea & & HQ650636 & DQ780271 & DQ780303 & DQ986736 & DQ870931 & - & GQ272390 \\
\hline Aspicilia cinerea & & HQ650637 & DQ780272 & DQ780304 & DQ986735 & DQ870932 & - & GQ272391 \\
\hline Aleuria aurantia & & MH225453 & & AY544654 & AY544698 & & DQ247785 & \\
\hline Baeomyces rufus & F178482 (S) & AF448457 & DQ871016 & $J \times 000080$ & AF113718 & DQ870937 & - & JX000150 \\
\hline Botryotinia fuckeliana & & DQ491491 & AY544732 & AY544651 & AY544695 & DQ471116 & DQ247786 & XM_001556412 \\
\hline Buellia aethalea & F138222(S) & JX000098 & JX000115 & $J \times 000081$ & - & $J \times 000133$ & - & $J \times 000151$ \\
\hline Buellia disciformis & $\begin{array}{l}\text { Westberg 10-002 } \\
\text { (S) }\end{array}$ & AY143392 & JX000116 & JX000082 & AF241543 & - & - & JX000152 \\
\hline Bryoglossum gracile & & AY789421 & - & AY789420 & - & - & - & - \\
\hline Caliciopsis orientalis & & - & FJ190654 & DQ470987 & DQ471039 & DQ471185 & - & - \\
\hline Calicium viride & M. Prieto 3015 (S) & HQ650703 & AY584696 & AY340538 & - & - & - & JX000153 \\
\hline Calicium salicinum & & AY453645 & & KF157982 & KF157970 & - & KF157998 & \\
\hline Calycidium cuneatum & Wedin 8034 (S) & JX000114 & JX000117 & JX000083 & - & JX000134 & & JX000154 \\
\hline Candelaria concolor & & AF182075 & EF436460 & DQ986791 & - & - & DQ992419 & - \\
\hline Candelariella aurella & $\begin{array}{l}\text { Hermansson } \\
10056 \text { (UPS) } \\
\end{array}$ & EF535163 & AY853313 & AY853361 & - & DQ915594 & & JX000155 \\
\hline Candelariella reflexa & & EF535189 & - & $\begin{array}{l}\text { DQ912331 } \\
\text { AFTOL-ID } 1271\end{array}$ & DQ912309 & - & DQ912380 & - \\
\hline Candelariella terrigena & & HQ650602 & - & \begin{tabular}{|l|} 
DQ986745 \\
AFTOL-ID 227
\end{tabular} & DQ986730 & - & DQ992427 & - \\
\hline Candida albicans & & JN606311 & $\begin{array}{l}\text { AACQ01000290 } \\
\text { REGION: 9209.. } \\
10587\end{array}$ & $\begin{array}{l}\text { AACQ01000290 } \\
\text { REGION: } 7072 . . \\
8646 \\
\end{array}$ & - & - & XM713346 & - \\
\hline $\begin{array}{l}\text { Canoparmelia } \\
\text { caroliniana }\end{array}$ & & KY929409 & - & AY584634 & AY584658 & - & AY584683 & - \\
\hline Capnodium coffeae & & DQ491515 & FJ190609 & GU214400 & DQ247808 & DQ471162 & DQ247788 & - \\
\hline Capronia munkii & & AF050250 & FJ225723 & EF413604 & EF413603 & EF413605 & & - \\
\hline Capronia pilosella & & DQ826737 & & DQ823099 & DQ823106 & & DQ840561 & \\
\hline $\begin{array}{l}\text { Catapyrenium } \\
\text { daedaleum }\end{array}$ & M. Prieto 3051 (S) & JX000099 & JX000118 & EF643748 & EF689830 & EF689748 & - & JX000156 \\
\hline Curvularia brachyspora & & MG250426 & - & AF279380 & L36995.1 & - & AF107803.1 & - \\
\hline $\begin{array}{l}\text { Chaenotheca } \\
\text { brachypoda }\end{array}$ & M. Prieto 3023 (S) & AF297963 & JX000122 & JX000086 & - & JX000135 & - & - \\
\hline Chaenotheca furfuracea & $\begin{array}{l}\text { Wedin } 6366 \\
\text { (UPS) }\end{array}$ & JX000101 & JX000121 & JX000087 & JX000068 & JX000137 & - & JX000158 \\
\hline Chaenotheca gracilenta & Wedin 7022 (S) & $J \times 000100$ & JX000119 & JX000084 & JX000067 & - & - & JX000157 \\
\hline Chaenotheca trichialis & M. Prieto 3028 (S) & $\mathrm{JX000102}$ & JX000120 & JX000085 & JX000069 & JX000136 & - & JX000159 \\
\hline $\begin{array}{l}\text { Chaenothecopsis } \\
\text { viridialba }\end{array}$ & $\begin{array}{l}\text { Wedin } 6728 \\
\text { (UPS) }\end{array}$ & JX000103 & AY853317 & AY853365 & - & - & - & JX000160 \\
\hline
\end{tabular}




\begin{tabular}{|c|c|c|c|c|c|c|c|c|}
\hline Chaetomium globosum & & AY429056 & - & AY545729 & AY545725 & - & $\begin{array}{l}\text { AAFU01001128 } \\
\text { REGION: } 238 \\
.2979\end{array}$ & - \\
\hline Cheilymenia stercorea & & MH930238 & - & AY544661 & AY544705 & - & AY544733 & - \\
\hline Chlorencoelia sp. & ZW-Geo55-Clark & AY789352 & - & AY789351 & - & - & - & - \\
\hline $\begin{array}{l}\text { Chromocleista } \\
\text { malachitea }\end{array}$ & & - & FJ225777 & FJ358281 & FJ358346 & FJ358409 & - & - \\
\hline Ciboria batschiana & & AY526234 & - & AY789322 & & - & - & - \\
\hline Cladonia caroliniana & & MK179649 & - & AY584640 & AY584664 & - & AY584684 & - \\
\hline Coccomyces dentatus & & KF797433 & - & AY544657 & AY544701 & - & DQ247789 & - \\
\hline Coccotrema cucurbitula & & AF329162 & AF329161 & AF274092 & AF274114 & DQ870939 & - & GU980990 \\
\hline Coccotrema pocillarium & & AF329167 & AF329166 & AF274093 & AF274113 & DQ870940 & - & GU980992 \\
\hline $\begin{array}{l}\text { Cochliobolus } \\
\text { heterostrophus }\end{array}$ & & - & - & AY544645 & |AY544727 & - & DQ247790 & - \\
\hline Coprinus comatus & & JQ901444 & - & AY635772 & AY665772 & - & AY780934 & - \\
\hline Coprinopsis cinerea & & FJ904826 & - & AF041494 & M92991 & - & AACS01000026 & - \\
\hline $\begin{array}{l}\text { Chromocleista } \\
\text { malachitea }\end{array}$ & & - & FJ225777 & FJ358281 & FJ358346 & FJ358409 & - & - \\
\hline Cudonia lutea & WZ164 & AF433149 & - & KC833187 & - & - & - & - \\
\hline Cudoniella clavus & & AY789374 & - & AY789373 & - & - & - & - \\
\hline Cudoniella sp. & ZW 0068 & AY789342 & - & AY789341 & - & - & - & - \\
\hline Cudoniella clavus & & $\begin{array}{l}\text { JQ256415/ } \\
\text { AY789374 }\end{array}$ & - & DQ470944 & DQ470992 & - & DQ470888 & - \\
\hline Cyphelium inquinans & M. Prieto 3008 (S) & $\begin{array}{l}\text { AY450583/AY1433 } \\
95\end{array}$ & AY143404 & AY453639 & | U86695 & - & - & JX000161 \\
\hline Cyphelium tigillare & M. Prieto 3038 (S) & JX000104 & JX000123 & JX000088 & AF241545 & - & - & JX000162 \\
\hline Dendrographa minor & & DQ842015 & - & AF279382 & AF279381 & - & AY641034 & - \\
\hline $\begin{array}{l}\text { Dermatocarpon } \\
\text { miniatum }\end{array}$ & & MF521951 & - & AY584644 & AY584668 & - & DQ782863 & - \\
\hline Dermea acerina & & MH855942 & - & DQ247801 & DQ247809 & - & DQ247791 & - \\
\hline Diploschistes ocellatus & & AF228316 & - & AY605077 & AF038877 & - & DQ366253 & - \\
\hline Diaporthe eres & & MK024710 & - & AF408350 & DQ471015 & & DQ470919 & - \\
\hline Dibaeis baeomyces & & DQ782844 & AY300883 & AF279385 & - & DQ842011 & AY641037 & - \\
\hline $\begin{array}{l}\text { Diploschistes } \\
\text { scruposus }\end{array}$ & F178255 (S) & HQ650716 & AY584692 & AF279389 & |AF279388 & DQ870943 & & JX000163 \\
\hline Disciotis sp. & & AJ544207 & - & AY544667 & AY544711 & - & DQ470892 & - \\
\hline Disciotis venosa & F12784 (S) & DQ491503 & \begin{tabular}{|l|}
$J X 000124$ \\
\end{tabular} & AY544667 & AY544711 & DQ471131 & - & - \\
\hline Dothidea insculpta & & AF027764 & FJ190602 & DQ247802 & DQ247810 & DQ471154 & DQ247792 & - \\
\hline Dothidea sambuci & & AY883094 & & AY544681 & AY544722 & - & DQ522854 & - \\
\hline $\begin{array}{l}\text { Eupenicillium } \\
\text { javanicum }\end{array}$ & & GU981614 & FJ225778 & EF413621 & EF413620 & - & & - \\
\hline Endocarpon pallidulum & & HM237334 & - & DQ823097 & DQ823104 & - & DQ840559 & - \\
\hline Exophiala dermatitidis & & KU664383 & - & DQ823100 & DQ823107 & - & DQ840562 & - \\
\hline Exophiala nigra & & EF551550 & FJ225742 & FJ358244 & FJ358312 & FJ358375 & - & - \\
\hline Exophiala pisciphila & & KC354799 & - & DQ823101 & DQ823108 & - & DQ840563 & - \\
\hline Fabrella tsugae & & - & - & AF356694 & - & - & - & - \\
\hline Fusarium graminearum & & JX162395 & - & AY188924 & - & - & $\begin{array}{l}\text { AACM01000132 } \\
\text { REGION: } \\
154552 . .157390 \\
\end{array}$ & v \\
\hline Geoglossum nigritum & & DQ491490 & AY544740 & AY544650 & AY544694 & DQ471115 & DQ470879 & - \\
\hline Gnomonia gnomon & & AY818957 & - & AF408361 & DQ471019 & - & DQ470922 & - \\
\hline Graphis scripta & \begin{tabular}{|l|}
$\begin{array}{l}\text { Wedin } 6476 \\
\text { (UPS) }\end{array}$ \\
\end{tabular} & AF229195 & AY853322 & AY853370 & AF038878 & DQ870947 & - & JX000164 \\
\hline Gyalecta ulmi & L67816 (S) & HQ650713 & AY300888 & AF465463 & AF088237 & JX000138 & - & JX000165 \\
\hline Gyromitra californica & & EU837204 & - & AY544673 & AY544717 & - & DQ470891 & \\
\hline Helvella compressa & & KU739801 & - & AY544655 & AY544699 & - & DQ497613 & \\
\hline Heterodermia speciosa & $\begin{array}{l}\begin{array}{l}\text { Wetmore } 88030 \\
\text { (S) }\end{array} \\
\end{array}$ & JX000105 & JX000125 & JX000089 & - & - & - & JX000166 \\
\hline Heyderia abietis & OSC60392 & AY789290 & - & AY789289 & - & - & - & - \\
\hline Heyderia abietis & HMAS71954 & AY789297 & - & AY789296 & - & - & - & - \\
\hline
\end{tabular}




\begin{tabular}{|c|c|c|c|c|c|c|c|c|}
\hline $\begin{array}{l}\text { Histoplasma } \\
\text { capsulatum }\end{array}$ & & AF129547 & - & - & - & - & - & - \\
\hline Holwaya mucida & & DQ257357 & - & DQ257356 & - & - & - & - \\
\hline $\begin{array}{l}\text { Hymenoscyphus } \\
\text { scutula }\end{array}$ & & AY789432 & - & AY789431 & - & - & - & - \\
\hline Hypocenomyce scalaris & $\begin{array}{l}\begin{array}{l}\text { Wedin } 7008 \\
\text { (UPS) }\end{array} \\
\end{array}$ & HQ650632 & AY853325 & $\begin{array}{l}\text { AY853373/ } \\
\text { DQ986748 } \\
\end{array}$ & |DQ782886 & |DQ915596 & DQ782875 & JX000167 \\
\hline Icmadophila ericetorum & & - & DQ986897 & DQ883694 & DQ883704 & DQ883723 & & - \\
\hline Lachnum virgineum & & MH857308 & - & AY544646 & AY544688 & - & DQ470877 & - \\
\hline Lecanactis abietina & & AY548804 & AY548813 & AY548812 & AY548805 & GU561850 & - & - \\
\hline Lecanora paramerae & & EF105413 & EF105418 & EF105422 & - & DQ870950 & - & - \\
\hline Lecidea fuscoatra & & HQ650707 & DQ912275 & DQ912332 & DQ912310 & DQ912355 & - & - \\
\hline Lecidea silaceae & & HQ650629 & DQ986878 & AY756340 & DQ986723 & DQ986820 & - & - \\
\hline $\begin{array}{l}\text { Lempholemma } \\
\text { polyanthes }\end{array}$ & M. Prieto 3052 (S) & ) JX000106 & - & |JX000090 & AF356690 & - & - & JX000168 \\
\hline Leotia lubrica & & AY144561 & - & AY544644 & AY544687 & - & DQ470876 & - \\
\hline Lepraria lobificans & & HQ650623 & DQ986887 & DQ986768 & DQ986733 & DQ986837 & - & - \\
\hline Leptogium lichenoides & & HQ650672 & DQ923120 & DQ917412 & DQ917413 & DQ917414 & - & - \\
\hline Lobaria pulmonaria & \begin{tabular}{|l} 
Wedin 6167 \\
(UPS)
\end{tabular} & HM448799 & AY340504 & AY340548 & AF183935 & DQ915591 & - & JX000169 \\
\hline Lobothallia radiosa & & JF703124 & DQ780274 & DQ780306 & - & DQ870954 & - & GQ272397 \\
\hline Magnaporthe grisea & & KM484885 & & AB026819 & AB026819 & & XM362269 & \\
\hline Microcalicium ahlneri & \begin{tabular}{|l|}
$\begin{array}{l}\text { Wedin 12/6 } 2011 \\
\text { (S) }\end{array}$ \\
\end{tabular} & JX000108 & JX000126 & - & JX000070 & |JX000139 & - & JX000170 \\
\hline Microglossum sp. & |PDD70355 & DQ257363 & - & - & - & - & - & - \\
\hline Mollisia cinerea & M. Prieto 3055 (S) & DQ491498 & |DQ976372 & DQ470942 & DQ470990 & FJ238440 & DQ470883 & JX000172 \\
\hline Monascus purpureus & & DQ782847 & FJ225780 & DQ782908 & DQ782881 & DQ842012 & - & - \\
\hline Morchella aff. esculenta & & AB509785 & - & AY544664 & AY544708 & - & DQ470880 & - \\
\hline Monilinia fructicola & & KY038837 & - & AY544670 & AY544714 & - & DQ470889 & - \\
\hline $\begin{array}{l}\text { Mycoblastus } \\
\text { sanguinarius }\end{array}$ & & JF744960 & - & DQ782915 & DQ782879 & - & DQ782867 & - \\
\hline Mycocalicium subtile & Wedin 8492 (S) & AF225445 & AY853330 & AY853379 & JX000072 & JX000141 & - & JX000173 \\
\hline Nectria cinnabarina & F118002(S) & HM484710 & FJ713622 & AF193237 & JX000073 & GQ506027 & - & JX000174 \\
\hline Neofabraea alba & & AY359236 & - & AY064705 & - & - & - & - \\
\hline Neofabraea malicorticis & & AF281386 & - & AY544662 & - & - & - & - \\
\hline Neurospora crassa & & KF040479 & - & AF286411 & X04971 & - & XM952013 & - \\
\hline Orbilia vinosa & & DQ491511 & - & DQ470952 & DQ471000 & - & - & - \\
\hline Orbilia auricolor & & DQ656611 & - & DQ470953 & DQ471001 & - & DQ470903 & - \\
\hline Ochrolechia parella & & AF332123 & GU980977 & AF274097 & AF274109 & DQ870959 & - & GQ272421 \\
\hline Ombrophila violacea & & AY789366 & - & AY789365 & - & - & - & - \\
\hline Onygena corvina & & - & FJ225792 & FJ358287 & FJ358352 & FJ358414 & - & - \\
\hline Ophioparma lapponica & & KF360414 & - & DQ973028 & - & - & - & - \\
\hline Ophioparma ventosa & & KF360415 & & \begin{tabular}{|l} 
KF360474/ \\
KJ766611
\end{tabular} & - & - & - & - \\
\hline $\begin{array}{l}\text { Orceolina kerguelensis } \\
\text { Orceolina kerguelensis }\end{array}$ & & AY212814 & - & AY212830 & |DQ366257 & - & DQ3662560 & - \\
\hline Parmelia saxatilis & \begin{tabular}{|l|} 
Wedin 7091 \\
(UPS)
\end{tabular} & AF058037 & AY340514 & AY300849 & AF117985 & DQ923695 & - & JX000175 \\
\hline Parmelia sulcata & & GU994574 & GU994669 & GU994621 & - & EF092135 & - & - \\
\hline Peltigera aphthosa & \begin{tabular}{|l} 
Wedin 6164 \\
(UPS)
\end{tabular} & AF158645 & AY340515 & AF286759 & AY424225 & |DQ915598 & - & JX000176 \\
\hline Peltigera degenii & & MH758420 & - & AY584657 & AY584681 & - & AY584688 & - \\
\hline Peltula auriculata & & DQ832329 & DQ922953 & DQ832330 & DQ832332 & DQ782856 & - & - \\
\hline Peltula umbilicata & & DQ832333 & DQ922954 & DQ832334 & DQ782887 & DQ782855 & - & - \\
\hline Pertusaria amara & & HQ650677 & AY300900 & AF274101 & AF356682 & DQ870965 & - & GQ272423 \\
\hline Pertusaria corallina & F178261 (S) & FR799261 & AY300901 & AY300850 & JX000074 & DQ870967 & - & GU980997 \\
\hline Pertusaria dactylina & & DQ782843 & - & DQ782907 & DQ782880 & - & DQ782868 & \\
\hline \begin{tabular}{|l} 
Pertusaria \\
hemisphaerica
\end{tabular} & & HQ650676 & |DQ973000 & AF381556 & DQ902340 & DQ902341 & - & GU980998 \\
\hline Pertusaria pertusa & & AF332127 & AF381565 & AF279300 & AY779282 & DQ870978 & - & - \\
\hline Pertusaria scaberula & & - & AF431959 & AF274099 & AF274105 & DQ870980 & - & GU981003 \\
\hline Pertusaria velata & F76497 (S) & JX000109 & GU980981 & AY300855 & JX000075 & DQ870982 & - & GU981005 \\
\hline
\end{tabular}




\begin{tabular}{|c|c|c|c|c|c|c|c|c|}
\hline $\begin{array}{l}\text { Peziza proteana } f . \\
\text { sparassoides }\end{array}$ & & JF908566 & - & AY544659 & AY544703 & - & - & - \\
\hline Peziza arvernensis & & KP125489 & - & AF133162 & - & - & - & - \\
\hline Peziza varia & & JF908557 & - & MG871335 & - & - & - & - \\
\hline Peziza vesiculosa & & JF908568 & - & DQ470948 & DQ470995 & - & DQ470898 & - \\
\hline Pneumocystis carinii & & KY197742 & - & AF047831 & S83267.1 & - & AY485631 & - \\
\hline Phialocephala helvetica & & AY347413 & - & & - & - & - & - \\
\hline \begin{tabular}{|l|} 
Phylliscum \\
demangeonii
\end{tabular} & \begin{tabular}{|l} 
Wedin 7241 \\
(UPS)
\end{tabular} & JX000110 & AY853333 & AY853382 & - & JX000142 & - & |JX000177 \\
\hline Phyllopsora sp. & & MG926004 & - & KF157990 & KF157978 & - & KF158005 & - \\
\hline Physcia aipolia & & EU682185 & - & DQ782904 & DQ782876 & - & DQ782862 & - \\
\hline $\begin{array}{l}\text { Placopsis } \\
\text { contortuplicata }\end{array}$ & & DQ534479 & - & EF489925 & - & - & - & - \\
\hline Placopsis gelida & & AF274084 & - & AY212836 & - & - & - & - \\
\hline Placynthiella icmalea & & AF274082 & - & EU940160 & - & - & - & - \\
\hline $\begin{array}{l}\text { Pleopsidium } \\
\text { clorophanum }\end{array}$ & M. Prieto 3056 (S) & EU870691 & DQ991756 & DQ842017 & |AY316151 & DQ782858 & - & JX000178 \\
\hline Pleopsidium gobiense & & HQ650723 & DQ991755 & DQ883698 & DQ525552 & DQ883746 & - & - \\
\hline Pleospora herbarum & & AB938190 & - & DQ247804 & DQ247812 & - & DQ247794 & - \\
\hline Protomyces inouyei & & MK045398 & - & AY548294 & AY548295 & - & AY548299 & - \\
\hline Podospora anserina & & MF380264 & - & - & - & - & - & - \\
\hline Potebniamyces pyri & & EU156058 & - & DQ470949 & DQ470997 & - & DQ470900 & - \\
\hline Pseudevernia furfuracea & & AY611112 & AY611169 & AY607826 & AY548817 & DQ870990 & - & - \\
\hline Pycnora praestabilis & & KF360399 & - & KJ766644 & - & - & - & - \\
\hline Pycnora sorophora & & KF360406 & - & AY853387 & MH468790 & - & MH468793 & \\
\hline Pycnora xanthococca & & KF360412 & - & KF360472 & & - & - & \\
\hline Pyrenula pseudobufonia & & DQ782845 & AY584720 & AY640962 & AY641001 & DQ840558 & - & - \\
\hline Pyrgillus javanicus & & DQ826741 & FJ225774 & DQ823103 & DQ823110 & DQ842010 & DQ842009 & XM_001586126 \\
\hline Pyronema domesticum & & MH758709 & - & DQ247805 & DQ247813 & - & DQ247795 & \\
\hline \begin{tabular}{|l|} 
Pyrenophora \\
phaeocomes
\end{tabular} & & DQ491507 & - & DQ499596 & |DQ499595 & - & DQ497614 & \\
\hline Pyxine sorediata & \begin{tabular}{|l} 
Wetmore 91254 \\
(S)
\end{tabular} & JX000111 & JX000129 & JX000093 & - & - & - & JX000179 \\
\hline Ramalina complanata & & HQ650720 & DQ972986 & DQ973038 & DQ883784 & DQ973059 & - & - \\
\hline Rhinocladiella anceps & & AY163559 & - & DQ823102 & DQ823109 & - & DQ840564 & - \\
\hline Rhytisma salicimum & & AY465516 & - & HM140566 & - & - & - & - \\
\hline Rimularia limborina & & KJ462273 & - & KJ462349 & - & - & - & - \\
\hline $\begin{array}{l}\text { Saccharomyces } \\
\text { cerevisiae }\end{array}$ & & KC542799 & - & $\begin{array}{l}\text { U53879 REGION: } \\
24144 . .25525\end{array}$ & Z75578 & - & Z75059 & - \\
\hline Sarcoscypha coccinea & & KU973865 & - & AY544647 & AY544691 & - & DQ497612 & - \\
\hline & & ITS & mtSsu & nuLsu & nussu & RPB1 & RPB2 & MCM7 \\
\hline Sarea difformis s.l. & CB093 (H) & MN938392 & - & MN938400 & - & - & - & - \\
\hline Sarea difformis s.l. & JR6451 (H) & MN938393 & MN938398 & MN938401 & MT028543 & - & MN938406 & - \\
\hline Sarea difformis s.I. & CBS 379.59 & MH857896 & - & MH867108 & - & - & - & - \\
\hline Sarea resinae s.I. & CB094 (H) & MN938395 & & MN938403 & - & - & - & - \\
\hline Sarea resinae s.l. & $\mathrm{JR} 6450(\mathrm{H})$ & MN938394 & MN938399 & MN938402 & MT028544 & - & MN938407 & MN938409 \\
\hline Sarea resinae s.I. & CBS 428.52 & MH857111 & - & MH869439 & - & - & - & - \\
\hline Sarea resinae s.l. & CBS 441.34 & MH855597 & - & MH867108 & - & - & - & - \\
\hline Sarea resinae s.l. & PDD 117345 & MN938397 & - & MN938405 & MT028545 & - & - & - \\
\hline Sarea resinae s.I. & $\begin{array}{l}\text { PDD } 117343 \\
\text { Abies } \\
\end{array}$ & MN938396 & - & MN938404 & MT028546 & - & MN938408 & - \\
\hline Simonyella variegata & & DQ782835 & - & AY584645 & AY584669 & - & DQ782861 & - \\
\hline Schistophoron tenue & L64691 (S) & JX000112 & EU544933 & EU544932 & - & - & - & JX000181 \\
\hline Schizoxylon albescens & Wedin 8365 (S) & HQ287353 & DQ401142 & DQ401144 & JX000077 & JX000143 & - & JX000182 \\
\hline Schizoxylon albescens & & JX000077 & - & - & - & - & - & - \\
\hline Scleromitrula shiraiana & & AY789408 & - & AY789407 & - & - & - & - \\
\hline Sclerophora farinacea & \begin{tabular}{|l} 
Wedin 6414 \\
(UPS)
\end{tabular} & JX000113 & JX000130 & JX000095 & JX000078 & JX000144 & - & JX000183 \\
\hline Sclerotinia sclerotiorum & & AF455526 & - & AY789347 & - & - & - & - \\
\hline
\end{tabular}




\begin{tabular}{|c|c|c|c|c|c|c|c|c|}
\hline Scutellinia scutellata & 1 & FJ235141 & L- & DQ247806 & DQ247814 & - & DQ247796 & | \\
\hline $\begin{array}{l}\text { Sphaerophorus } \\
\text { globosus }\end{array}$ & \begin{tabular}{|l} 
Stenroos 5539 \\
(TUR)
\end{tabular} & HQ650622 & DQ986866 & DQ986767 & AF117983 & DQ986836 & - & JX000185 \\
\hline Spathularia flavida & WZ 214 & - & - & MH868630 & - & - & - & - \\
\hline Sphinctrina turbinata & & AY795877 & FJ71361 & EF413632 & EF413631 & - & - & - \\
\hline Spiromastix warcupii & & DQ782848 & FJ225794 & DQ782909 & DQ782882 & EF413613 & DQ782870 & - \\
\hline Sordaria fimicola & & KY930619 & - & AY545728 & AY545724 & - & - & - \\
\hline Staurothele frustulenta & & KC990385 & - & DQ823098 & DQ823105 & - & DQ840560 & - \\
\hline Stictis radiata & & MH578520 & - & AF356663 & U20610 & - & AY641079 & - \\
\hline $\begin{array}{l}\text { Symbiotaphrina } \\
\text { lignicola }\end{array}$ & CBS 325.93 & MH862405 & - & NG_057675 & & - & - & - \\
\hline $\begin{array}{l}\text { Symbiotaphrina } \\
\text { buchneri }\end{array}$ & & KY105569 & - & KY109806 & AY227716 & - & JСM9740 & - \\
\hline Symbiotaphrina kochii & AFTOL-ID 1902 & - & - & - & FJ176833 & - & FJ238443 & - \\
\hline Symbiotaphrina kochii & $\begin{array}{l}\text { CBS } \\
588.63 / 589.63\end{array}$ & DQ248314 & - & - & U26207 & - & DQ248316 & - \\
\hline Symbiotaphrina kochii & CBS 250.77 & MH861058 & - & NG_057719 & U26206 & - & GU397369 & - \\
\hline Symbiotaphrina kochii & DC-1-15 & KC215110 & - & - & - & - & - & - \\
\hline Symbiotaphrina kochii & DC-1-75 & KC215113 & - & - & - & - & - & - \\
\hline Taphrina wiesneri & & AB435051 & - & AY548292 & AY548293 & - & AY548298 & - \\
\hline Thamnolia vermicularis & & AY853345 & AY853395 & - & AF085472 & - & - & - \\
\hline $\begin{array}{l}\text { Trematosphaeria } \\
\text { heterospora }\end{array}$ & & GQ203795 & - & AY016369 & AY016354 & - & DQ497615 & - \\
\hline Trapelia involuta & & - & - & AF274098 & - & - & - & - \\
\hline Trapelia placodioides & & AF274081 & AF431962 & AF274103 & AF119500 & DQ366259 & DQ366260 & \\
\hline Trapeliopsis flexuosa & & HQ650634 & AY212875 & AF274118 & DQ986709 & DQ871000 & 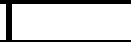 & - \\
\hline $\begin{array}{l}\text { Trapeliopsis } \\
\text { glaucolepidea } \\
\end{array}$ & & - & - & - & - & - & - & - \\
\hline Trapelia placodioides & & - & - & KU844623 & - & & - & - \\
\hline $\begin{array}{l}\text { Trichoglossum } \\
\text { hirsutum }\end{array}$ & F39542(S) & DQ491494 & AY544758 & AY544653 & AY544697 & DQ471119 & - & JX000188 \\
\hline Roccella fuciformis & & KF036010 & - & AY584654 & AY584678 & & DQ782866 & \\
\hline Umbilicaria hyperborea & Wiklund 25 (UPS) & AF096216 & AY853349 & AY853399 & - & DQ915600 & - & JX000189 \\
\hline Verrucaria muralis & & EU010261 & FJ225708 & EF689878 & EF689878 & EF689805 & - & GQ272418 \\
\hline Vibrissea albofusca & & AY789384 & - & AY789383 & - & - & - & - \\
\hline Vibrissea flavovirens & & AY789427 & - & AY789426 & - & - & - & - \\
\hline Vibrissea truncorum & & AY789403 & - & AY789402 & - & - & - & - \\
\hline $\begin{array}{l}\text { Westerdykella } \\
\text { cylindrica }\end{array}$ & & DQ491519 & - & AY779322 & AY016355 & - & DQ470925 & - \\
\hline $\begin{array}{l}\text { Xylographa } \\
\text { opegraphella }\end{array}$ & & - & - & KJ462364 & - & - & - & - \\
\hline Xylona haveae & CBS 132.468 & MH866027 & - & MH877475 & - & - & - & - \\
\hline Xylona heveae & CBS 132.557 & NR_121539 & - & MH878330 & NG_061134 & - & - & - \\
\hline Xylona heveae & TC118 & JQ838233 & - & - & - & - & - & - \\
\hline Xylona heveae & TC161 & JQ838232 & - & JQ838238 & JQ838237 & - & - & - \\
\hline Xylona heveae & TC137 & JQ838234 & - & JQ838240 & JQ838235 & - & JQ838245 & - \\
\hline Xylona heveae & TC269 & JQ838225 & - & JQ838236 & JQ838239 & - & JQ838246 & - \\
\hline Xylaria acuta & & JQ862676 & - & AY544676 & AY544719 & - & DQ247797 & - \\
\hline Xylaria hypoxylon & F118002(S) & DQ491487 & AY544760 & AY544648 & AY544692 & DQ471114 & DQ470878 & JX000190 \\
\hline
\end{tabular}


Table S2. Primers used for specific gene amplification of fungal DNA. Sequencing primers are identical to those used in PCR.

\begin{tabular}{|c|c|c|}
\hline Primer name/Publication & Primer Sequence & PCR conditions \\
\hline ITS1F/ Gardes \& Bruns (1993) & 5'-CTT GGT CAT TTA GAG GAA GTA A-3' & \multirow[t]{2}{*}{$\begin{array}{l}\text { (1) } 95^{\circ} \mathrm{C} \text { for } 2 \min (2) 35 \text { cycles of } 45 \mathrm{~s} \text { at } 95^{\circ} \mathrm{C}, 45 \mathrm{~s} \\
\text { at } 52^{\circ} \mathrm{C} \text { and } 45 \mathrm{~s} \text { at } 72{ }^{\circ} \mathrm{C}(3) 72{ }^{\circ} \mathrm{C} \text { for } 10 \mathrm{~min}\end{array}$} \\
\hline ITS4/White et al. (1990) & 5'-TCC TCC GCT TAT TGA TAT GC-3' & \\
\hline LR0R/ Rehner \& Samuels (1994) & 5'-ACCCGCTGAACTTAAGC-3' & \multirow[t]{2}{*}{$\begin{array}{l}\text { (1) } 95^{\circ} \mathrm{C} \text { for } 2 \min (2) 35 \text { cycles of } 45 \mathrm{~s} \text { at } 95^{\circ} \mathrm{C}, 45 \mathrm{~s} \\
\text { at } 52^{\circ} \mathrm{C} \text { and } 45 \mathrm{~s} \text { at } 72{ }^{\circ} \mathrm{C}(3) 72^{\circ} \mathrm{C} \text { for } 10 \mathrm{~min}\end{array}$} \\
\hline LR5/Vilgalys \& Hester (1990) & 5'-TCCTGAGGGAAACTTCG-3' & \\
\hline LR7/Vilgalys \& Hester (1990) & 5'-TACTACCACCAAGAT CT-3' & \multirow[t]{2}{*}{$\begin{array}{l}\text { (1) } 95^{\circ} \mathrm{C} \text { for } 2 \min (2) 35 \mathrm{cycles} \text { of } 45 \mathrm{~s} \text { at } 95^{\circ} \mathrm{C}, 50 \mathrm{~s} \\
\text { at } 52^{\circ} \mathrm{C} \text { and } 60 \mathrm{~s} \text { at } 72{ }^{\circ} \mathrm{C}(3) 72^{\circ} \mathrm{C} \text { for } 10 \mathrm{~min}\end{array}$} \\
\hline LR3R/ Moncalvo et al. (2000) & 5'-GTCTTGAAACACGGA CC-3' & \\
\hline Mcm7-709/ Schmitt et al. (2009) & 5'-ACI MGI GTI TCV GAY GTH AAR CC-3' & \multirow[t]{2}{*}{$\begin{array}{l}\text { (1) } 95^{\circ} \mathrm{C} \text { for } 2 \min (2) 35 \text { cycles of } 45 \mathrm{~s} \text { at } 95^{\circ} \mathrm{C}, 50- \\
60 \mathrm{~s} \text { at } 50-52^{\circ} \mathrm{C} \text { and } 60 \mathrm{~s} \text { at } 72{ }^{\circ} \mathrm{C}(3) 72^{\circ} \mathrm{C} \text { for } 10 \\
\text { min }\end{array}$} \\
\hline Mcm7-1348/ Schmitt et al. (2009) & 5'-GAY TTD GCI ACI CCI GGR TCW CCC AT-3' & \\
\hline NS1/ White et al. (1990) & 5'- GTA GTC ATA TGC TTG TCT C-3' & \multirow[t]{2}{*}{$\begin{array}{l}\text { (1) } 95^{\circ} \mathrm{C} \text { for } 2 \min (2) 35 \text { cycles of } 45 \mathrm{~s} \text { at } 95^{\circ} \mathrm{C}, 50- \\
60 \mathrm{~s} \text { at } 50-52^{\circ} \mathrm{C} \text { and } 60 \mathrm{~s} \text { at } 72{ }^{\circ} \mathrm{C}(3) 72^{\circ} \mathrm{C} \text { for } 10 \\
\text { min }\end{array}$} \\
\hline NS4/ White et al. (1990) & 5'-CTTCCGTCAATTCCTTTAAG-3' & \\
\hline
\end{tabular}




\begin{tabular}{|c|c|c|}
\hline RPB1-AFasc/Hofstetter et al. (2007) & 5'-ADTGYCCYGGYCATTTYGGT-3' & \multirow[t]{4}{*}{$\begin{array}{l}\text { (1) } 95^{\circ} \mathrm{C} \text { for } 2 \min (2) 40 \text { cycles of } 50 \mathrm{~s} \text { at } 95^{\circ} \mathrm{C}, 60 \mathrm{~s} \\
\text { at } 52-55^{\circ} \mathrm{C} \text { and } 60 \mathrm{~s} \text { at } 72{ }^{\circ} \mathrm{C}(3) 10 \mathrm{~min} \text { at } 72^{\circ} \mathrm{C} \text {. }\end{array}$} \\
\hline RPB1-6R2asc/ Hofstetter et al. (2007) & 5'-ATGACCCATCATRGAYTCCT-3' & \\
\hline RPB1-DF2asc/ Hofstetter et al. (2007) & 5'-CAYAAGGARTCYATGATGG-3' & \\
\hline RPB1G1R/ Hofstetter et al. (2007) & 5'-ACNCCNACCATYTCNCCNGG-3' & \\
\hline fRPB2-5F/ Liu et al. (1999) & 5'-GAYGAYMGWGATCAYTTYGG-3' & \multirow[t]{2}{*}{$\begin{array}{l}\text { (1) } 95^{\circ} \mathrm{C} \text { for } 2 \mathrm{~min}(2) 40 \mathrm{cycles} \text { of } 50 \mathrm{~s} \text { at } 95^{\circ} \mathrm{C}, 60 \mathrm{~s} \\
\text { at } 50-55^{\circ} \mathrm{C} \text { and } 60 \mathrm{~s} \text { at } 72^{\circ} \mathrm{C}(3) 10 \mathrm{~min} \text { at } 72^{\circ} \mathrm{C} \text {. }\end{array}$} \\
\hline fRPB2-7cR/ Liu et al. (1999) & 5'-CCCATRGCTTGYTTRCCCAT-3' & \\
\hline TSR1453/ Schmitt et al. (2009) & 5'-GAR TTC CCI GAY GAR ATY GAR CT-3' & \multirow[t]{2}{*}{$\begin{array}{l}\text { (1) } 95^{\circ} \mathrm{C} \text { for } 2 \mathrm{~min}(2) 35-40 \text { cycles of } 45 \mathrm{~s} \text { at } 95^{\circ} \mathrm{C} \text {, } \\
50 \mathrm{~s} \text { at } 52{ }^{\circ} \mathrm{C} \text { and } 60 \mathrm{~s} \text { at } 72{ }^{\circ} \mathrm{C}(3) 10 \text { at } 72{ }^{\circ} \mathrm{C} \text {. }\end{array}$} \\
\hline TSR2308/ Schmitt et al. (2009) & 5'-CTT RAA RTA ICC RTG IGT ICC-3' & \\
\hline
\end{tabular}

\section{References}

Hofstetter V, Miadlikowska J, Kauff F, et al. (2007). Phylogenetic comparison of protein-coding versus ribosomal RNA-coding sequence data: A case study of the Lecanoromycetes (Ascomycota). Molecular Phylogenetics and Evolution 44: 412-426.

Gardes M, Bruns TD (1993). ITS primers with enhanced specificity for basidiomycetes_application to the identification of mycorrhizae and rusts. Molecular Ecology 2: 113-118. 


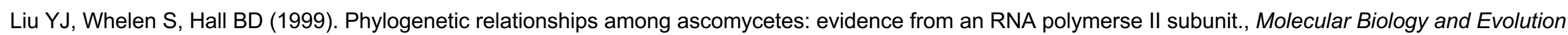
16: 1799-1808.

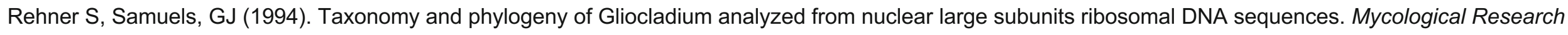
98: $625-634$.

Schmitt I, Crespo A, Divakar PK, et al. (2009). New primers for promising single-copy genes in fungal phylogenetics and systematics. Persoonia 23: 35-40.

Vilgalys R Hester M (1990). Rapid genetic identification and mapping of enzymatically amplified ribosomal DNA from several Cryptococcus species. Journal of Bacteriology 172: 4238-4246.

White TJ, Bruns T, Lee S, et al. (1990). Amplification and direct sequencing of fungal ribosomal RNA genes for phylogenetics. In: PCR Protocols: a guide to methods and applications (Innis MA, Gelfand DH, Sninsky JJ, et al., eds). Academic Press, USA: 315-322. 